\title{
Genotype influence on shelf life behaviour of minimal processed loquat (Eriobotrya japonica (Thunb.) Lindl.) fruit: the role of sugar, acid organics and phenolic compounds
}

\author{
Giuseppe Sortino ${ }^{1}$, Alessio Allegra ${ }^{*}{ }^{*} \mathbb{D}$, Vittorio Farina ${ }^{1}$, Maria Lucia Valeria De Chiara ${ }^{2}$ and Paolo Inglese ${ }^{1}$
}

\begin{abstract}
Background: Loquat cultivars cultivated in Southern Italy are very appreciated by consumers for their sensorial characteristics, such as persistent aroma and taste. Apposite maturity indexes for peeling and processing loquat fruit were investigated to increase diffusion of minimally processed loquat. The genotype's effect on the minimally processed loquat fruit shelf life and quality harvested at commercial maturity (80\% yellow color) was investigated on peeled fruit stored at $5^{\circ} \mathrm{C}$ for 10 days. The role of sugars, organic acids and phenols composition was observed through in depth qualitative analysis. In addition, several qualitative analyses were carried out to determine the quality of minimal processed fruit.
\end{abstract}

Results: Loquat fruits harvested at commercial ripening stage performed very good palatability and flesh color persistency. Late ripening fruits genotypes shown a low rate of pulp oxidation and quality decay, while early ripening fruits were not suitable for fresh-cut. Genotype had a great influence on weight loss, $\beta$-carotene content, fruit respiration, ascorbic acid and total phenols content during the shelf life.

Conclusions: This work shows how the amount of the composition of sugars and organic acids as an intrinsic characteristic of genotype influences the quality of loquat fruits minimal processed. The higher values of glucose, sorbitol and ascorbic acid accumulated in the cv'Nespolone Trabia' contributed to a reduction in chilling injury and oxidative stress after cutting.

Keywords: Eriobotrya japonica, Microbial spoilage, Fresh-cut, Flavor score, Sucrose, Succinic acid

\footnotetext{
*Correspondence: alessio.allegra@unipa.it

1 Department of Agriculture, Food and Forestry Sciences, Viale delle

Scienze Ed. 4, ing. H., Palermo 90128, Italy

Full list of author information is available at the end of the article
} 


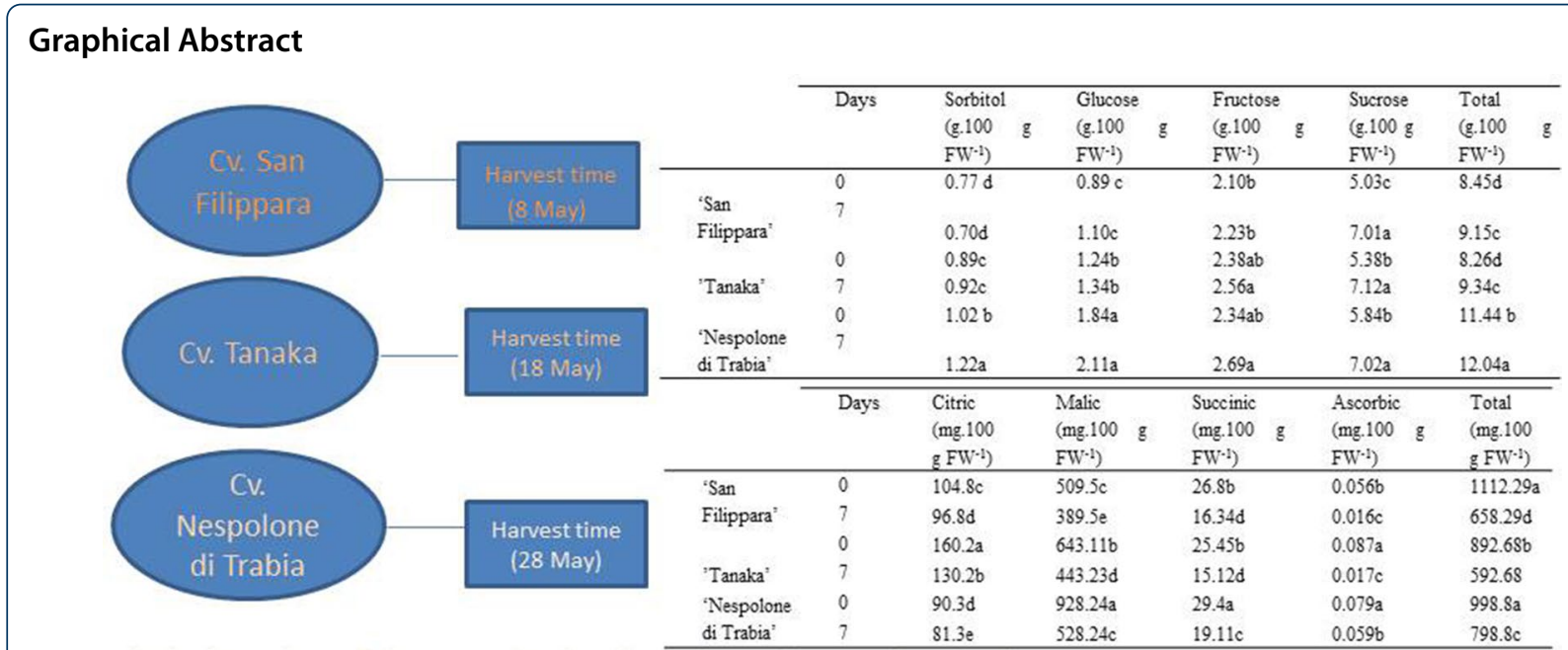

The higher values of glucose, sorbitol and ascorbic acid accumulated in the cy 'Nespolone Trabia' contributed to a reduction in chilling injury and oxidative stress after cutting
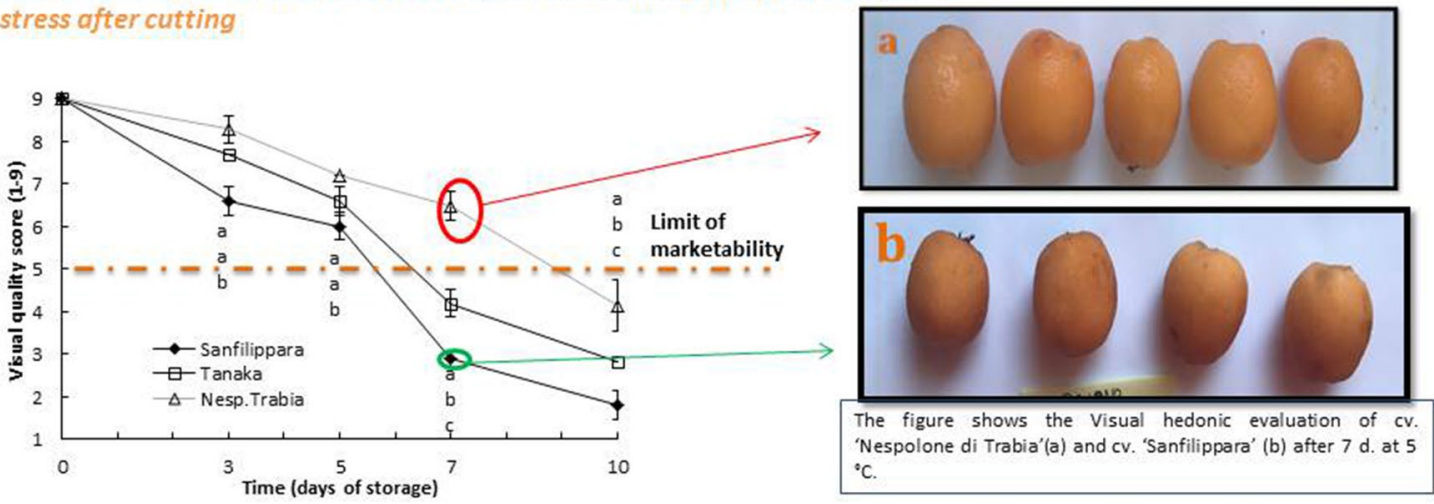

\section{Introduction}

Loquat (Eriobotrya japonica (Thunb). Lindl.) cultivars grown in the Mediterranean area are local and international genotypes characterized by succulent, white, yellow or orange flesh and a sweet to sub-acid or acid taste [1]. A total of 536 metabolites were identified on two loquat cultivars white and yellow-fleshed, 193 of which include 7 carbohydrates, 12 organic acids and 8 amino acids [2]. Local genotypes are largely diffused in Italy, but their marketable quality is not properly defined [3]. Loquat fruit is classified as non-climacteric fruit $[4,5]$ and requires about 120-150 days from full bloom in December [6] to fruit ripening in April-May. Determination of ripeness can be divided into five stages [7], and it is important, because unripen fruits are excessively acid.

Due to scalar on-tree ripening, harvest of loquat fruit lasts for several weeks, depending on genotype $[8,9]$. Loquat fruit is susceptible to chilling injury and to scab (Fusicladium eriobotryae), which symptoms appear throughout flower and fruit development, with the most serious damage occurring in leaves and fruits during wet seasons, when control measures are inadequate [10]. To the best of our knowledge, so far there were very few attempts to test minimal processing on loquat fruit. So far, studies about shelf life of minimally processed fruit focused largely on appearance, neglecting taste, texture and nutraceutical compounds. Flesh of loquat fruit contains carotenoids that are responsible for the color of loquat fruit, the most abundant ones being $\beta$-carotene, $\beta$-cryptoxanthin, lutein, violaxanthin, $\alpha$-carotene and $\gamma$-carotene [11]. During postharvest, loquat fruit may have severe problems of flesh browning caused by enzymatic oxidation [12]. Some authors show that loquat fruits retained their initial quality and chemical components for 30 days during storage in micro-perforated polyethylene (PE) film packaging at 1 and $5{ }^{\circ} \mathrm{C}[12,40]$.

However, consumer acceptance of flavor, aroma and taste is crucial to ensure a stable and continuous 
commercialization in the market. In fact, these sensory attributes are very important indicators of shelf life even for non-expert consumers [13]. Unfortunately, in preserved fresh fruit, flavor tend to deteriorate faster than appearance according to consumers [14]. Therefore, the maintenance of satisfactory gustatory sensory characteristics of the processed fruit, together with a good level of nutraceutical compounds, may allow a brand to consolidate its position on the market, creating loyalty in consumers who appreciate them. In loquat, sucrose and sorbitol are the main photosynthetic products and the main form of translocated carbon [15], those of which can be used as fuel during the ripening process [16] and be converted to glucose and fructose with specific enzymes. Soluble sugars also exert positive effects to protect plant cells from damage caused by cold stress [17]. Glucose [18] and fructose [19] play a very important role in protecting plants and fruits from cold but not always involved in this process. These sugars are used as osmoregulators, cryoprotectants, signaling molecules, and scavengers of reactive oxygen species [20] to protect plants from chilling stress. Furthermore, we believe that high sugar content and higher activities of hexokinase, were also beneficial to sugar signal generation, enhancing the chilling resistance of loquat fruit [21].

In loquat fruit there are 15 volatile compounds as: phenylethanol, 3-hydroxy-2-buta-none, phenylacetaldehyde, and isomeric hexen-1-ols, ethylacetate, methyl cinnamate,b-ionone [22], hexanal, (E)-2-hexenal and benzaldehyde [23]. Large variability in fruit components occur in relation to loquat genotype. In cv. 'Tanaka' hexanal, (E)-2-hexenal, hexanoic acid and $\beta$-ionone significantly contribute to fruit aroma, while phenylacetaldehyde is the most important aroma component [24]. In Akko XIII, 'Champagne de Grasse', 'Guzelyurt 6, 'Hafif Cukurgobek', 'KKTC 3', 'KKTC 4' and 'Sayda' cultivars, positive correlations occurred between antioxidant capacity and total phenolic content [25]. The activity of the enzyme peroxidase increased from the green phase to the color change, the enzymes such as pectin methyl esterase, cellulose and polygalacturonase showed a constant reduction from the green to the orange phase, and polyphenol oxidase showed no change during ripening in the 'Golden Nugget' cultivar [26]. Amoros [27], in addition, reported that flesh firmness decreased in different loquat fruit cultivars during the last 4-5 weeks of development. This decrease was more pronounced and occurred first for cvs. 'Cardona' and 'Magdall'. Firmness values for mature fruits were similar for the cultivars 'Algerie', 'Magdall' and 'Peluche', while in 'Cardona' fruit they were significantly lower. No information exists on shelf life behavior of minimally processed loquat fruit. We investigated the effect of an early and late ripeness stage and the role of sugar and acid organic, phenolic compound on shelf life behavior of minimal processing loquat fruit (Eriobotrya japonica (Thunb.) Lindl).

\section{Materials and methods \\ Plant material and orchard descriptions}

This research was conducted in 2019, on yellow-flesh loquat (Eriobotrya japonica (Thunb). Lindl) cultivars 'Tanaka,' 'Sanfilippara,' 'Nespolone di Trabia', grafted onto loquat seedling rootstock, grown in a commercial orchard, located in Castelvetrano (Trapani, Italy) (Latitude $37^{\circ} 40^{\prime} 50^{\prime \prime} \mathrm{N}$; Longitude: $12^{\circ} 47^{\prime} 30^{\prime \prime} \mathrm{E}, 80 \mathrm{~m}$ a.s.l.), planted in 2009. This orchard is managed according to the organic farming protocol. Trees are grown to full globe, spaced at $5 \times 4 \mathrm{~m}$ apart, branched about $1.2 \mathrm{~m}$ above the ground and reach 3 to $3.5 \mathrm{~m}$ in height. The soil was managed by leaving a permanent cover of grass, mowed once or twice in spring. This practice allows trees to intercept solar radiations and supply nutrients, improving the efficiency of the ecosystem. An efficient ecosystem implies the use of fewer inputs to produce, because it is able to maximize its potential, and consequently, a reduction in cultivation costs. The trees were pruned after harvesting in late spring to renew the fruiting wood and encourage light penetration into the canopy. The average annual rainfall for the district in which the orchard is located amounts to about $500 \mathrm{~mm}$ and average day/night temperatures during the last 4 weeks of fruit ripening were $28 / 23^{\circ} \mathrm{C}$.

\section{Harvesting method and sample preparations}

The proper maturity stage for peeling and processing was evaluated on 30 fruits for each cultivar at each maturity stage (commercial ripe 'CM' $=80 \%$ yellow, $20 \%$ orange ground color; full ripe 'FR' $=100 \%$ orange color $[4,26$, 28]. Regarding to peel color, fruit total soluble solid content (TSS), fruit peelabilty Cefola et al. 2013 [29] and flesh color after peeling, were evaluated using a 9-pt hedonic scale ( $9=$ very high and $1=$ very low) but all qualitative and biochemical analyses were performed at harvest for both ripening stages (CM and FR). Only fruit harvested at commercial maturity (CM) stage were used for further analysis.

Three hundred and thirty fruits of each cultivar were hand-picked at commercial harvest time that was on 8 May for cv. 'Sanfilippara'; 18 May for cv 'Tanaka'; 28 May for cv. 'Nespolone di Trabia', and transferred to the post-harvest laboratory. The sampled fruits of the three cultivars were sanitized by immersion in $200 \mathrm{mg} \mathrm{kg}^{-1}$ of sodium hypochlorite for $5 \mathrm{~min}$ and then dried at room temperature $\left(16 \pm 2{ }^{\circ} \mathrm{C}\right)$. Peeling was performed manually in a refrigerated room at $5 \pm 1{ }^{\circ} \mathrm{C}$ and the fruits were placed in polyethylene terephthalate (PET) 
boxes $(500 \mathrm{cc})$ in a passive atmosphere and sealed with a composite film (PP-PET, $64 \mu \mathrm{m}, \mathrm{O}_{2}$ permeability $=5.30 \times 10^{-8} \mu \mathrm{L} \mathrm{m}^{-2} \mathrm{~s}^{-1} \mathrm{~Pa}^{-1}$. The boxes were stored at $5 \pm 0.5{ }^{\circ} \mathrm{C}$ and $90 \%$ relative humidity (RH) for 10 days (T0, T3, T5, T7, T10). Chemical and physical parameters were analyzed at the beginning of the experiment (T0) and then after 3, 5, 7 and 10 days of storage. Each box was used as single replicate for each cultivar (3 cultivars $\times 5$ time of storage $\times 9$ replicates (T0, T3, T5, T7, T10) $=135$ box). Each box contained 6 fruits (135 box $\times 6$ fruits $=810$ fruits).

\section{Physicochemical analyses}

\section{Ethylene production at harvest}

Ethylene production and fruit respiration rate were measured immediately after harvest both at $20{ }^{\circ} \mathrm{C}$ and after storage at $4{ }^{\circ} \mathrm{C}$ for $72 \mathrm{~h}$. Ten fruit were weighed with a digital scale and placed individually in $705-\mathrm{mL}$ sealed glass containers, according to Crisosto [30]. In intact fruit following harvest, ethylene production $\left(\mu \mathrm{L} \mathrm{kg}^{-1} \mathrm{~h}^{-1}\right)$ was measured in an acclimatized chamber at $20^{\circ} \mathrm{C}$. According to previous literature, gas samples $(1 \mathrm{~mL})$ were taken of effluent air from respiration jars, using a $1 \mathrm{~mL}$ syringe and injected into a gas chromatograph (GC, Agilent Technologies 6890, Wilmington, Germany) and fitted with a FID detector and an alumina column F1 80/100 ( $2 \mathrm{~m} \AA \sim 1 / 8 \AA \sim 2.1$, Tecknokroma, Barcelona, Spain). The oven temperature was $140{ }^{\circ} \mathrm{C}$, while the injector and detector were kept at 180 and $280^{\circ} \mathrm{C}$, respectively.

\section{Respiration rate during storage}

Six fruits per treatments per time were enclosed in $1 \mathrm{~L}$ glass jars at $5{ }^{\circ} \mathrm{C} .10 \mathrm{~mL}$ of headspace gas was taken from each jar after $2 \mathrm{~h} . \mathrm{CO}_{2}$ was measured with GC (Agilent Technologies 6890, Wilmington, Germany). Respiration rate was expressed in $\mathrm{mL} \mathrm{CO}_{2} \mathrm{~kg}^{-1}$ fresh weight (FW) $\mathrm{h}^{-1}$

\section{Weight loss}

The weight (g) of each tray of 6 fruits was recorded using a $0.01 \mathrm{~g}$ precision balance (Gibertini, Italy), immediately after harvest at T0 (day 0) and subsequently at 3, 5, 7 and 10 days of storage. Weight loss was estimated as a percentage (\%) reduction from the initial time, using the following equation

Weight loss \% : [(initial weight of fruit bags - final weight of fruit bags $) \times 100] /$ initial weight of fruit bags. sub-sample were homogenized with $10 \mathrm{~mL}$ of deionised water using a polytron homogenizer (IKA Labotechnik) and centrifuged at 10,000 $\mathrm{g}$ for $10 \mathrm{~min}$. An aliquot of $10 \mathrm{~mL}$ of the supernatant was used to quantify sugars and organic acids by HPLC (Hewlett-Packard, series 1100, Waldbrom, Germany) chromatograph equipped with a SUPELCOGEL C-610H (30 cm $7.8 \mathrm{~mm}$ ) column (at $30 \mathrm{C}$ ), a refractive index detector (for sugar analysis) and an UV-V detector $(210 \mathrm{~nm}$, for acid analysis). The elution system consisted of $0.1 \% \mathrm{H}_{3} \mathrm{PO}_{4}$, running isocratically at a flow rate of $0.5 \mathrm{~mL} \mathrm{~min}^{-1}$. Two separate extractions were made from each sub-sample of 5 fruits and for each extraction, sugars and organic acids were determined in duplicate.

\section{Color}

The color of each fruit (six replicates for each cultivar and sampling date) was measured with a portable colorimeter (Minolta Chroma Meter CM400R, Minolta, Osaka, Japan), equipped with an 8-mm measuring head and a $\mathrm{C}$ illuminant (6774K). The instrument was calibrated using the manufacturer's standard white plate.

Within the CIELAB uniform space, a psychometric index of lightness, $L^{*}$ (ranging from 0 , black, to 100, white) and two-color coordinates $a^{*}$ (which takes positive values for reddish colors and negative values for greenish ones) and $b^{*}$ (positive for yellowish colors and negative for the bluish ones) are defined. Total color difference $\left(\Delta E^{*}\right)$ expressed the magnitude of difference between the initial non-aged color pulp (zero time) and storageaged samples. Total color difference $\left(\Delta E^{*}\right)$ was calculated according to the following:

$$
\Delta \mathbf{E}^{*}=\sqrt{\Delta L^{* 2}+\Delta a^{* 2}+\Delta b^{* 2}}
$$

where $\Delta a^{*}=a^{*}-a 0^{*}, \Delta b^{*}=b^{*}-b 0^{*}, \Delta L^{*}=L^{*}-L 0^{*}$; $a 0^{*}, b 0^{*}$ and $L 0^{*}$ are the corresponding blank values of control sample, and $a 0^{*}=-2.00, b 0^{*}=4.00$ and $L 0^{*}=80.00$, respectively. All data were reported as mean \pm standard error $(\mathrm{SE}, n=6)$.

\section{Visual appearance, flavor score, peeling, change color and crunchiness score}

To measure the effect of storage on fruit visual traits (color, visible structural integrity and visual appearance) at each storage period, six replicates for each cultivar and

\section{Soluble sugar and organics acid}

Soluble sugar and organics acid were extracted from fruits and analyzed by HPLC, according to a method described by Amoros [27]. Five grams of loquat mesocarp from each time of storage were scored by six scientific judges, using a subjective 9-1 acceptance scale from $9=$ very good (just peeled), to $1=$ very poor (inedible). To measure the effect of cold storage on fruit flavor traits at each storage 
time, six fruit, used as six replicates for each cultivar and time sampling date were scored by six scientific judges, using a subjective 9-1 acceptance scale from $9=$ very high to $1=$ none.

The crunchiness of each loquat was determined by six judges, based on the resistance of fruit to chewing, according to a $9-1$ scale, from $9=$ very crunchy to $1=$ crummy (inedible). Each judge analyzed a sample of six fruit used as six replicates for each cultivar at each sampling date.

The peelability score of each loquat fruit was determined by six judges, based on the resistance of fruit to peeling, according to a scale from $9=$ high peelability to $1=$ no peelability.

Flesh color change score after peeling was determined by six judges according to a scale from $9=$ very high to $1=$ imperceptible.

\section{Sensory evaluation}

Fruits were tested to evaluate the organoleptic characteristics through a semi-trained panel tests.

The sensory profile was defined by a panel of 10 judges ( 5 females and 5 males, between 22 and 45 years of age) with extensive experience in the sensory evaluation of other types of fruit Gentile [31]. Before each evaluation, trained panelists signed consent forms for voluntary participation in the present study. Training was conducted in three orientation sessions of $2 \mathrm{~h}$ each, wherein panelists developed scales to score fruit sensory descriptors [32]. For training purposes and familiarization, to panelists were given fruit pieces of various level of quality. Loquat sensory evaluations, on postprocessing, were conducted under white fluorescent light. 16 attributes were chosen by the judges in a preliminary meeting on the basis of frequency of citation (> 60\%): appearance (APP), pulp color (PC), Consistency $(\mathrm{C})$, fruity odour (FO), herbaceous odour (GO), off-odour (OFO), sweet (S), acid (A), juiciness (J), astringent (AST), pungent $(\mathrm{P})$, fruity flavor (FFL), fermented flavor (FFE), flavour alcohol (ALF), off-flavour (OFF), overall evaluation (OVE). Panelists performed "difference from control" discrimination sensory test for the degree of sensory descriptors on a 1-9 scoring scale; 1 and 9, respectively, correspond to "no difference" and "extremely different" from the control, respectively. Each sample (at harvest, and after 3, 5, 7 and 10 days of storage), was presented in a white plastic plate with a 3-digit code on the side and tasted $1 \mathrm{~h}$ after they were taken out of the $5{ }^{\circ} \mathrm{C}$ cold room. Sparkling water for rinsing between samples and unsalted crackers to neutralize mouth feel were provided to the panelists.

\section{Package $\mathrm{O}_{2}$ and $\mathrm{CO}_{2}$ analysis}

$\mathrm{CO}_{2}$ and $\mathrm{O}_{2}$ levels (\%) were measured on each box at the beginning of each experiment and after 3, 5, 7 and 10 days of storage, using a PBI Dansensor Checkpoint $\mathrm{O}_{2}$ and $\mathrm{CO}_{2}$ analyzer (Topac, Hingham, MS, USA) with zirconium and infrared detectors, respectively.

\section{Carotenoids extraction}

Carotenoids were extracted from fruits and analyzed by HPLC, according to a method previously described by Xiong [33]. Component's identification and quantitative analysis were done using Agilent 1200 HPLC-DAD analysis system, $5 \mu \mathrm{m} \mathrm{C} 18 \mathrm{~m}$ reverse phase column (250 mm $\times 4.6 \mathrm{~mm}$, Japan) and $20 \mathrm{~mm} \times 4.6 \mathrm{~mm} \mathrm{C18}$ pre column maintained at $35{ }^{\circ} \mathrm{C}$. Using external standard method. The compounds $\beta$-carotenoid, and lutein were detected at different stages. The standard samples of $\beta$-carotenoid and lutein were purchased from Sigma-Aldrich Company (Ge). The concentration of $\beta$-carotenoid and lutein were calculated from the experimental peak area by analytical interpolation in a standard calibration curve and was expressed as $\mathrm{mg} 100 \mathrm{~g}^{-1}$ of fresh weight.

\section{Extraction and separation of phenolic compounds}

Twenty grams of freshly prepared pulp was homogenized in $80 \mathrm{~mL}$ of cold methanol (95\%) for $1 \mathrm{~min}$, shaken for $10 \mathrm{~min}$, and filtered. The pellet was extracted twice again with cold methanol (80\%). The combined extracts were evaporated under vacuum at $35{ }^{\circ} \mathrm{C}$ until the methanol was removed. The concentrate was then extracted with hexane three times to remove lipids, carotenoids, and chlorophyll. The aqueous phase was evaporated again to remove the hexane. Finally, water was added to the extract to constitute a total of $50 \mathrm{~mL}$. Total phenolics were determined with the Folin-Ciocalteu phenol reagent using this extract solution. For identification and quantification, with HPLC column was a fused-core Poroshell 120, SB-C18 $(3.0 \times 100 \mathrm{~mm}, 2.7 \mu \mathrm{m})$ from Agilent Technologies (Agilent Technologies, Palo Alto, CA, USA) Separation was carried out with different gradient dilution programs depending on the phenolic classes (0 min, 5\% B; 2 min, 7\% B; 4 min, 9\% B; 6 min, 12\% B; 8 min, 15\% B; 9 min, 16\% B; 10 min, 17\% B; 11 min, $17.5 \%$ B; $12 \mathrm{~min}, 18 \% \mathrm{~B} ; 14 \mathrm{~min}, 20 \% \mathrm{~B} ; 16 \mathrm{~min}, 28 \% \mathrm{~B} ; 18 \mathrm{~min}$, $100 \%$ B; 22 min, $100 \%$ B; 23 min, 5\% B).

\section{Acid ascorbic content}

The ascorbic acid concentration was determined according to Rapisarda and Intelisano [34] using liquid chromatography HPLC (Perkin Elmer, Australia), with an 
injector (Rheodyne with $20 \mathrm{uL}$ loop), a photodiode detector, and a Knauer Eurospher II 100-5 C18 column $250 \mathrm{~mm} 4.6 \mathrm{~mm}$ I.D. (Berlin, Germany), and a similarly packed precolumn. The dilution was performed with a buffer solution consisting of $\mathrm{KH}_{2} \mathrm{PO}_{4} / \mathrm{H}_{3} \mathrm{PO}_{4}$ at $\mathrm{pH} 2.3$, at

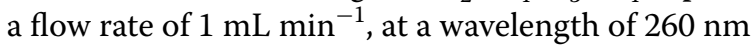

\section{Statistical analysis}

The experimental design was made with three cultivars: 'Tanaka,' 'Sanfilippara' and 'Nespolone di Trabia'. Observations were made at $T 0$ and after 3, 5, 7 and 10 days of storage at $5 \pm 0.5{ }^{\circ} \mathrm{C}$ and with $90 \%$ relative humidity. ANOVA (SYSTAT ${ }^{\mathrm{TM}}$ statistical software v.13.0, USA, for Windows was used) was performed and mean values were compared with Tukey's test during storage, for each storage time and for each cultivar. Significant differences were calculated with $p \leq 0.05$.

\section{Results and discussion}

Loquat fruits during the last days of ripeness involve physical-chemical changes that lead the fruit to the mature stage for commercial distributions, after 24, 48 or $36 \mathrm{~h}$, depending on temperature, the ripeness stage at this stage, the fruit will have reached a stage of development change in physiological ripeness in which its quality will be at least the minimum acceptable for consumers [35]. All the values of chemical and physical composition of loquat fruit evaluated over time were influenced by the ripeness stage. The maturity stages of peel color yellow (CM) and orange (FR) present significant different $(p \leq 0.05)$ characteristics in terms of fruit quality (Table 1). Besada [36] reported that some volatile compounds show a rapid increase with full ripening of loquat fruits. A large group of volatile, mostly alcohols (aliphatic, methyl and ethyl alcohols) and, to a lesser extent, aldehydes, ketones and esters compounds, did not have showed dramatic changes during last stages of ripeness. Fruit of 'Sanfilippara,' 'Tanaka' and 'Nespolone di Trabia' harvested at commercial maturity (CM) had a higher peelability, a higher ethylene production and a higher tritatable acidity, crunchiness score, lutein and $\beta$-carotene content than those harvested at fully ripe stage (FR). The genotype had a significant $(p \leq 0.05)$ influence on ethylene production at $20{ }^{\circ} \mathrm{C}$. Moreover, $\mathrm{CM}$ fruit showed a significatively lower change in color after peeling than FR ones (Table 1). Similar results are reported in loquat fruit of cvs. 'Karantoki' and 'Morphitiki' cultivated in Cyprus [8].

\section{Respiration rate, weight loss, headspace gas and color}

Loquat fruit is a non-climacteric fruit that exhibits a decrease in respiration rate. In our experiment, loquat fruit values show some significant differences (T7 and T10) among cultivars for each time of storage, the respiration remains stable for 10 days, during storage at $5{ }^{\circ} \mathrm{C}$ (Fig. 1).

Weight loss sharply increased 7 days after storage and only at this stage significant differences among genotypes occurred (Fig. 2), while TSS and TA did not significantly change during shelf life (data not shown). Loquat fruit, after peeling and packaging in passive atmosphere, showed a progressive increase of $\mathrm{CO}_{2}$ and a decrease in $\mathrm{O}_{2}$ as in fresh cut peach with or without chemicals treatment [30,36]. Samples of cv

Table 1 Quality parameters of 'Sanfilippara', 'Tanaka' and 'Nespolone di Trabia' loquat fruit harvested at commercial ripeness (CM=10\% green ground-color $70 \%$ yellow and $20 \%$ orange color) and fully ripe ( $F R=60 \%$ yellow and $40 \%$ orange color)

\begin{tabular}{|c|c|c|c|c|c|c|}
\hline & \multicolumn{2}{|c|}{ 'Sanfilippara' } & \multicolumn{2}{|c|}{ 'Tanaka' } & \multicolumn{2}{|c|}{ ‘Nespolone di Trabia' } \\
\hline & $(\mathrm{CM})$ & (FR) & (CM) & (FR) & (CM) & (FR) \\
\hline Peelability score ${ }^{a}$ & $7.0 \mathrm{a}$ & $5.2 b$ & $8.4 a$ & $5.1 b$ & $7.4 a$ & $5.4 b$ \\
\hline $\begin{array}{l}\text { Ethylene production at } 20^{\circ} \mathrm{C}\left(\mu \mathrm{L} \mathrm{C}_{2} \mathrm{H}_{4}\right. \\
\left.\mathrm{kg}^{-1} \mathrm{~h}^{-1}\right)\end{array}$ & $9.5 \mathrm{a}$ & $2.3 b$ & $8.7 a$ & $1.9 b$ & $6.3 a$ & $1.7 \mathrm{~b}$ \\
\hline Crunchiness score (1-9) & $9 a$ & $5.3 b$ & $9 a$ & $6.1 b$ & $9 a$ & $6.6 b$ \\
\hline Lutein content $\mu \mathrm{g} \mathrm{g}^{1}$ (FW) & $10.2 \mathrm{a}$ & $5.1 \mathrm{~b}$ & $9.11 \mathrm{a}$ & $4.2 \mathrm{~b}$ & $8.44 a$ & $3.6 b$ \\
\hline$\beta$-Carotene content $\mathrm{mg} \mathrm{g}^{-1}(\mathrm{FW})$ & 3.0a & $5.2 \mathrm{~b}$ & $2.4 a$ & $4.6 b$ & $1.5 \mathrm{a}$ & $4.3 b$ \\
\hline \multicolumn{7}{|c|}{ Flesh color change after peeling ( $20 \mathrm{~min}$ at $25^{\circ} \mathrm{C}$ ) } \\
\hline$L^{*}$ & $58.4 a$ & $53.3 b$ & $59.4 a$ & $53.6 b$ & $58.6 a$ & $53.2 b$ \\
\hline$a^{*}$ & $14.2 \mathrm{a}$ & $11.2 b$ & $15.0 \mathrm{a}$ & $11.1 b$ & $14.7 a$ & $11.5 b$ \\
\hline$b^{*}$ & $44.6 b$ & $59.2 \mathrm{a}$ & $50.2 b$ & $58.5 \mathrm{a}$ & $49.6 b$ & $56.6 a$ \\
\hline Flesh color change after peeling ${ }^{b}$ & $1.5 b$ & $5.1 \mathrm{a}$ & $1.6 b$ & $4.6 \mathrm{a}$ & $1.4 b$ & $3.8 a$ \\
\hline
\end{tabular}

${ }^{a}$ Peelability score: to $9=$ high peelability a $1=$ no peelability. Mean values of 30 fruit for each cultivar

${ }^{b}$ Flesh color change after peeling (9-1) score: from $9=$ very high to $1=$ imperceptible. Mean values of 10 fruits for each cultivar and maturity stage (commercial ripeness $\mathrm{CM}$ and full ripeness $\mathrm{FR}$ ). Different letters indicate significant differences between ripening stages and within genotype, at $p \leq 0.05$ 


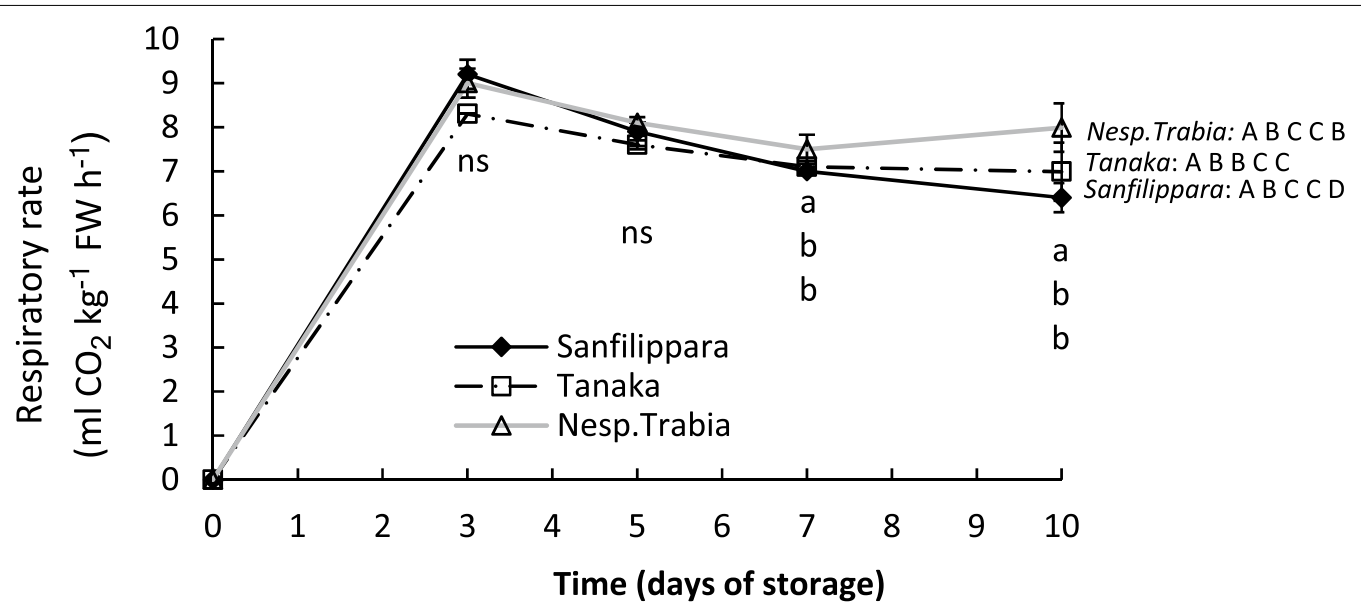

Fig. 1 Respiration rate of loquat fruit cv. 'Sanfilippara,'Tanaka' and 'Nespolone di Trabia' immediately after peeling (0) and stored for 3, 5, 7 and 10 days at $5^{\circ} \mathrm{C}(n=6$ replicates per cultivar and sampling date). For each cultivar, different capital letters indicate significant differences between sampling dates, and different lowercase letters indicate significant differences (Tukey's test at $p \leq 0.05$ ) between different cultivar at the same sampling date $(0,3,5,7$ and 10 days). Vertical bars represent standard error (SE)

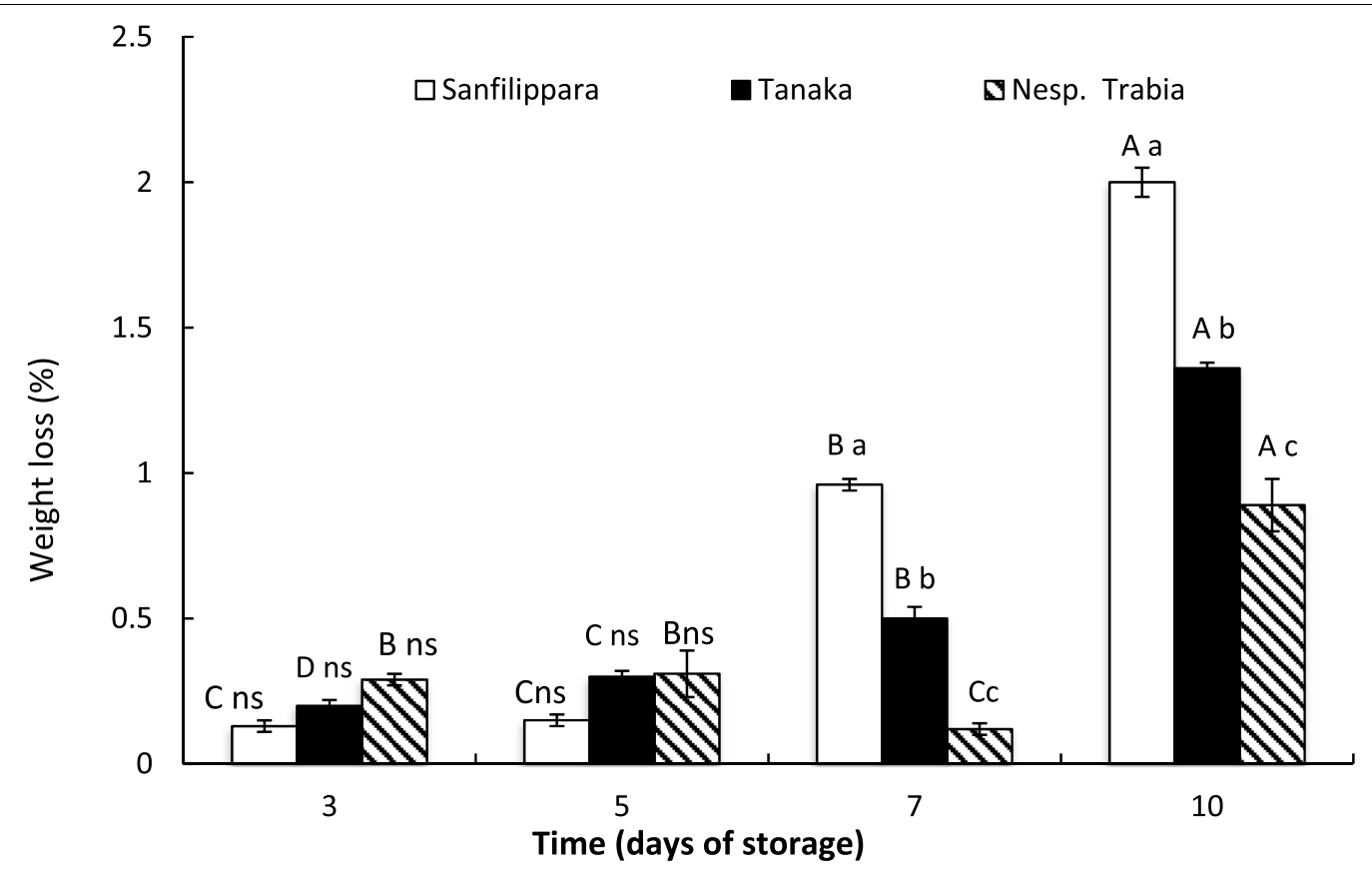

Fig. 2 Weight loss (\%) of loquat fruit cv. 'Sanfilippara,' 'Tanaka' and 'Nespolone di Trabia' immediately after peeling (0) and stored for 3, 5, 7 and 10 days at $5^{\circ} \mathrm{C}(n=6$ replicates per cultivar and sampling date). For each cultivar, different capital letters indicate significant differences between sampling dates, and different lowercase letters indicate significant differences (Tukey's test at $p \leq 0.05$ ) between different cultivar at the same sampling date $(0,3,5,7$ and 10 days). Vertical bars represent standard error (SE)

'Sanfilippara' showed a significant difference in terms of $\mathrm{CO}_{2} \mathrm{Kpa}$ in all times of storage than other genotypes. Regarding to oxygen concentration at 3th day of storage cv 'Nespolone di Trabia' shown higher values than cvs 'Sanfilippara' and 'Tanaka', while after 3 days and until the 7th day cv 'Sanfilippara' showed significant differences between loquat fruit cultivars. No differences occurred between genotypes during the last days of storage (Fig. 3). 


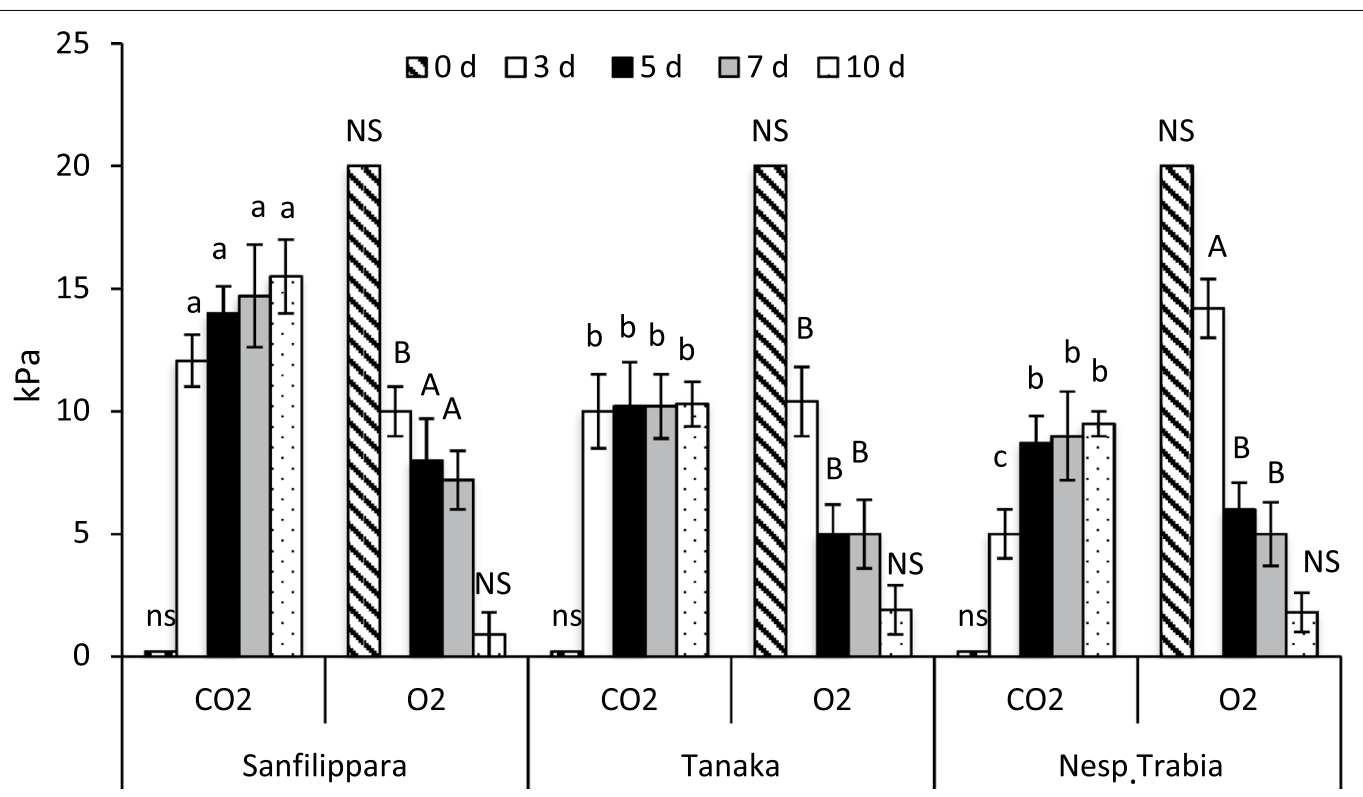

Fig. $3 \mathrm{CO}_{2}$ and $\mathrm{O}_{2}$ content in package of loquat fruit cv. 'Sanfilippara', 'Tanaka' and 'Nespolone di Trabia' immediately after peeling (0) and stored for $3,5,7$ and 10 days at $5{ }^{\circ} \mathrm{C}(n=6$ replicates per cultivar and sampling date). Different lowercase and capital letters indicate significant differences (Tukey's test at $p \leq 0.05)$ on $\mathrm{CO}_{2}$ and $\mathrm{O}_{2}$ content between sampling dates $(0,3,5,7$ and 10 days), respectively. Vertical bars represent standard error (SE)

For instance, fruit of cvs. 'Nespolone di Trabia' and 'Tanaka' kept $\mathrm{CO}_{2}$ values under $10 \%$ but cv. 'Sanfilippara' ones exceed $15 \%$ since 5 days after storage. Low $\mathrm{O}_{2}$ atmospheres have been shown to inhibit respiration through a shift to anaerobic respiration [37], with a development of ethanol [38]. Gao et al. [39] reported that fresh loquat fruit stored for 49 days at $1.1-1.4 \mathrm{kPaO}_{2}$ and $2-4{ }^{\circ} \mathrm{C}$ had lower decay, reduced respiration and ethylene production rates and inhibited activities of PPO and POD. According to other authors, the development of fermentative substance begins at high concentrations of $\mathrm{CO}_{2}$ and levels lower than $1 \%$ of $\mathrm{O}_{2}$ [37]. In our experiment, these conditions occurred only after 10 days of storage when $\mathrm{O}_{2}$ content was lower than $1 \%$ (Fig. 3). The color change of each cultivar during shelf life was measured as color change during time $(\Delta E)$ showed significant behaviors between cultivars and during storage (Fig. 4).

Flesh color of loquat fruit sharply changed during the first 3 days after storage. It is clear that the higher respiration rates are related to the change in color, as shown by 'Sanfilippara' fruit (Figs. 3, 4) 5 days after storage onwards. The color change between genotypes of the same population, have also been detected on different species [40] or using different treatments [41] for evaluate oxidation and freshness condition of fresh-cut fruit. Note that a $\Delta E$ value $>4$ is considered perceptible to human eyes [40].

\section{Soluble sugars and organic acids}

All loquat fruits ('Nespolone di Trabia' Tanaka' and 'San Filippara') significantly increase content in total sugars after 7 days of storage (Table 2). The cultivar 'Nespolone di Trabia' showed significantly higher values than cultivars 'Tanaka' and 'San Filippara'. Among the sugars, sucrose is the one that increases by about $19.8 \%$ in all cultivars, while sorbitol increases by about $15 \%$ in the lateripening $\mathrm{cv}$. On the other hand, in the early ripening cvs there is no significant increase.

Regarding to organic acids, malic acid is predominant both at harvest and after 7 days of storage. Malic acid was followed by citric, succinic and ascorbic acid (Table 3). After 7 days, malic acid decreases significantly in all cultivars by $45-60 \%$, while citric acid decrease by about $7.63-18.7 \%$. Loquat fruit is characterized by a low vitamin $C$ content [40] and the fruit shows a height variability between 0.46 and $13.80 \mathrm{mg}$ FW of ascorbic content within nine loquat cultivars, including five international affirmed cultivars: 'Algerie,' 'Golden Nugget', 'Peluche', 'Bueno', 'El Buenet' and four local cultivars: 'Sanfilippara,' 'Nespolone di Trabia,' 'BRT20' and 'Claudia' [31]. In other cvs ascorbic acid content was low and ranged from 4.17 to $8.33 \mathrm{mg}$ per $100 \mathrm{~g}$ indicated cultivar specific differences [22].

The resistance of change colour gives to 'Nespolone di Trabia' (Fig. 4) an optimal quality as a fresh cut product. Loquat fruit also contains ascorbic acid; however, when stored as a fresh cut fruit, the ascorbic acid content 


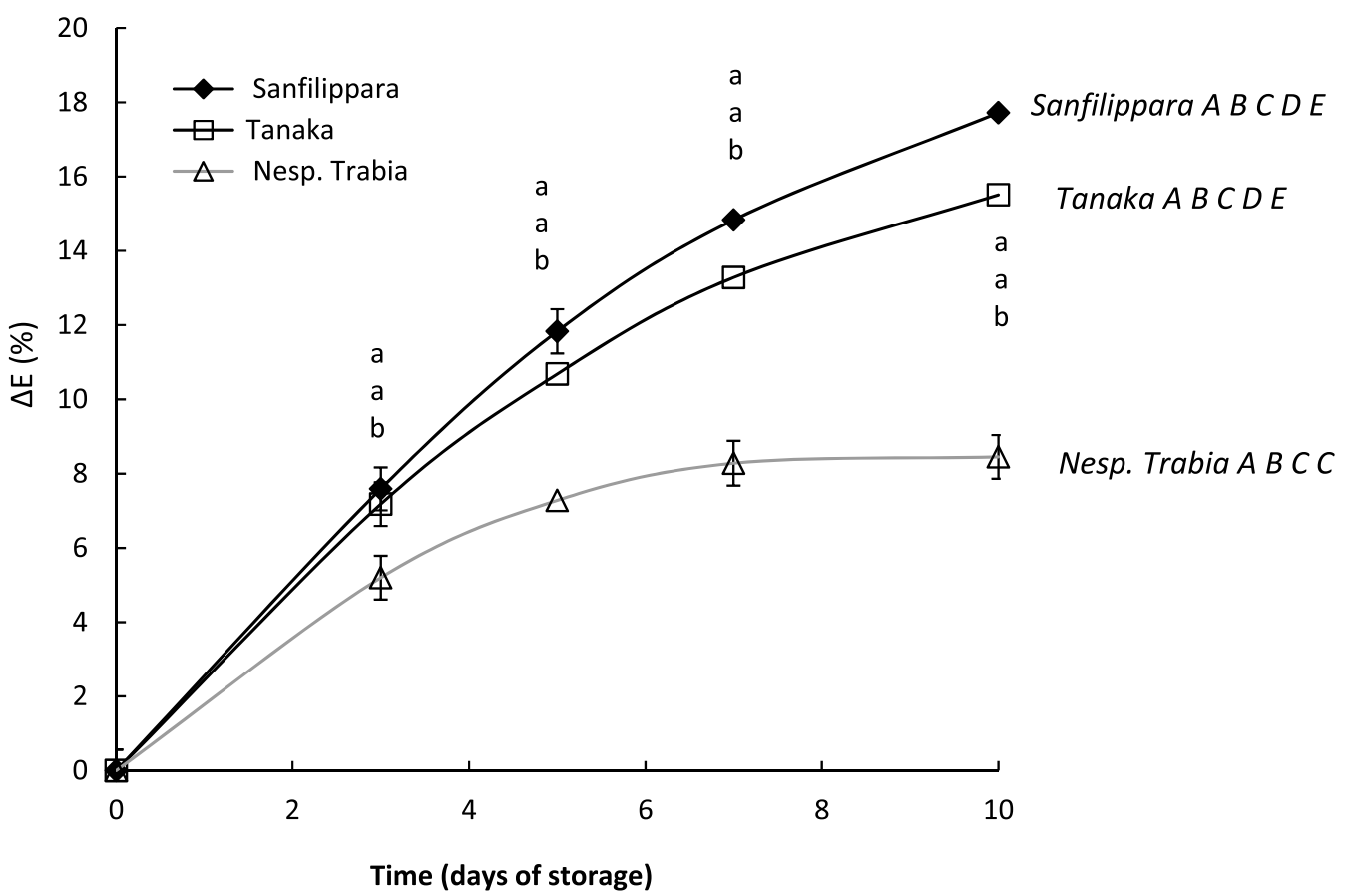

Fig. $4 \Delta E$ in loquat fruit cv. 'Sanfilippara,',Tanaka' and 'Nespolone di Trabia'immediately after peeling (0) and stored for 3, 5, 7 and 10 days at $5{ }^{\circ} \mathrm{C}$ ( $n=6$ replicates per cultivar and sampling date). For each cultivar, different capital letters indicate significant differences between sampling dates, and different lowercase letters indicate significant differences (Tukey's test at $p \leq 0.05)$ between different cultivar at the same sampling date $(0,3,5$, 7 and 10 days). Vertical bars represent standard error (SE)

Table 2 Total sugars, glucose, fructose, sorbitol, in minimal processed loquat fruit (cvs. 'San Filippara', 'Tanaka', 'Nespolone di Trabia') immediately after harvest

\begin{tabular}{|c|c|c|c|c|c|c|}
\hline & Days & $\begin{array}{l}\text { Sorbitol } \\
\left(\mathrm{g} 100 \mathrm{~g} \mathrm{FW}^{-1}\right)\end{array}$ & $\begin{array}{l}\text { Glucose (g } 100 \mathrm{~g} \\
\mathrm{FW}^{-1} \text { ) }\end{array}$ & $\begin{array}{l}\text { Fructose (g } 100 \mathrm{~g} \\
\mathrm{FW}^{-1} \text { ) }\end{array}$ & $\begin{array}{l}\text { Sucrose (g } 100 \mathrm{~g} \\
\left.\mathrm{FW}^{-1}\right)\end{array}$ & $\begin{array}{l}\text { Total } \\
(\mathrm{g} 100 \mathrm{~g} \\
\left.\mathrm{FW}^{-1}\right)\end{array}$ \\
\hline \multirow[t]{2}{*}{ San Filippara } & 0 & $0.77 d$ & $0.89 c$ & $2.10 \mathrm{~b}$ & $5.03 c$ & $8.45 d$ \\
\hline & 7 & $0.70 d$ & $1.10 c$ & $2.23 b$ & $7.01 \mathrm{a}$ & $9.15 c$ \\
\hline \multirow[t]{2}{*}{ Tanaka } & 0 & $0.89 c$ & $1.24 b$ & $2.38 a b$ & $5.38 b$ & $8.26 \mathrm{~d}$ \\
\hline & 7 & $0.92 \mathrm{C}$ & $1.34 b$ & $2.56 a$ & $7.12 \mathrm{a}$ & $9.34 \mathrm{C}$ \\
\hline \multirow[t]{2}{*}{ Nespolone di Trabia } & 0 & $1.02 \mathrm{~b}$ & $1.84 a$ & $2.34 a b$ & $5.84 b$ & $11.44 b$ \\
\hline & 7 & $1.22 \mathrm{a}$ & $2.11 \mathrm{a}$ & $2.69 a$ & $7.02 \mathrm{a}$ & $12.04 \mathrm{a}$ \\
\hline
\end{tabular}

Values with different letters are significantly different at $p<0.05$

decreases significantly during storage. The decrease in ascorbic acid during storage and processing in fruits and vegetables is a common phenomenon [41]. In fresh cut pineapple, the ascorbic acid content decreases during storage but the antioxidant capacity does not change, indicating that it is not only this organic compound that contributes to total antioxidant capacity [42]. Table 3 shows that the amount of ascorbic acid was higher in the cv. 'Nespolone di Trabia,' while it is lower in the other two cultivars; while citric acid compound is higher in cvs 'Tanaka' and 'Sanfilippara' then in cv 'Nespolone di Trabia'.

Our data indicate that ascorbic acid content decreased during storage with the same rate pattern in all genotypes, and until 7 days after storage in 2 out of 3 genotypes (Table 3). These results suggest that in loquat fruits, polyphenols contributed to antioxidant capacity much more than ascorbic acid and carotenoids content [18] when in other fruit predominated ascorbic [43] or citric acid [44]. 
Table 3 Organic acids, citric, malic, succinic and ascorbic acids in minimal processed loquat fruit (cvs. 'San Filippara', 'Tanaka', 'Nespolone di Trabia') immediately after harvest

\begin{tabular}{|c|c|c|c|c|c|c|}
\hline & Days & $\begin{array}{l}\text { Citric (mg } 100 \mathrm{~g} \\
\mathrm{FW}^{-1} \text { ) }\end{array}$ & $\begin{array}{l}\text { Malic (mg } 100 \mathrm{~g} \\
\mathrm{FW}^{-1} \text { ) }\end{array}$ & $\begin{array}{l}\text { Succinic (mg } 100 \mathrm{~g} \\
\mathrm{FW}^{-1} \text { ) }\end{array}$ & $\begin{array}{l}\text { Ascorbic (mg } 100 \mathrm{~g} \\
\mathrm{FW}^{-1} \text { ) }\end{array}$ & $\begin{array}{l}\text { Total } \\
\left(\mathrm{mg}^{100 \mathrm{~g}}\right. \\
\left.\mathrm{FW}^{-1}\right)\end{array}$ \\
\hline \multirow[t]{2}{*}{ San Filippara } & 0 & $104.8 \mathrm{c}$ & $509.5 \mathrm{c}$ & $26.8 b$ & $0.056 b$ & 1112.29a \\
\hline & 7 & $96.8 d$ & $389.5 \mathrm{e}$ & $16.34 d$ & $0.016 c$ & $658.29 d$ \\
\hline \multirow[t]{2}{*}{ Tanaka } & 0 & $160.2 a$ & $643.11 b$ & $25.45 b$ & $0.087 a$ & $892.68 b$ \\
\hline & 7 & $130.2 b$ & $443.23 d$ & $15.12 d$ & $0.017 c$ & 592.68 \\
\hline \multirow[t]{2}{*}{ Nespolone di Trabia } & 0 & $90.3 d$ & $928.24 a$ & $29.4 a$ & $0.079 a$ & $998.8 a$ \\
\hline & 7 & $81.3 e$ & $528.24 c$ & $19.11 \mathrm{C}$ & $0.059 \mathrm{~b}$ & $798.8 c$ \\
\hline
\end{tabular}

Values with different letters are significantly different at $p<0.05$

\section{Visual quality, flavor score and crunchiness score}

Loquat fruit quality is influenced by several factors, but during postharvest the one that regulates quality maintenance is the production of ethylene, even if the quantity after harvest is low. The use of 1-MCP (1-methylcyclopropene), in fact, inhibited the formation of lignin on fruits [45].

The amount of ethylene produced is different among different cultivars and storage temperature. After 8 days of storage at $20{ }^{\circ} \mathrm{C}$ on loquat fruits, flesh firmness increases and production respiration is reduced [21]. Amoròs et al., [27] show that different firmness values occurred between 'Algerie', 'Cardona', 'Golden', 'Magdall' and 'Peluche' during ripeness; Kahramanoglu [46] uses a value of flesh firmness at harvest of $0.4 \mathrm{~kg}^{-1}$ for his experiments on postharvest of loquat fruits. In this study visual appearance, flavor and crunchiness score (Figs. 5, $6,7,8)$ showed the same rate pattern with significant genotype differences related to their metabolic activity (Fig. 3).

Most significant changes and genotype differences occurred after 7 days of storage, when all scores declined rapidly, and only one genotype ('Nespolone di Trabia') kept its flavor, and visual and crunchiness score above the threshold marketability. Similar results were shown by Ding [47] on loquats in $20 \mu \mathrm{m}$ thick PE film at $5{ }^{\circ} \mathrm{C}$ with

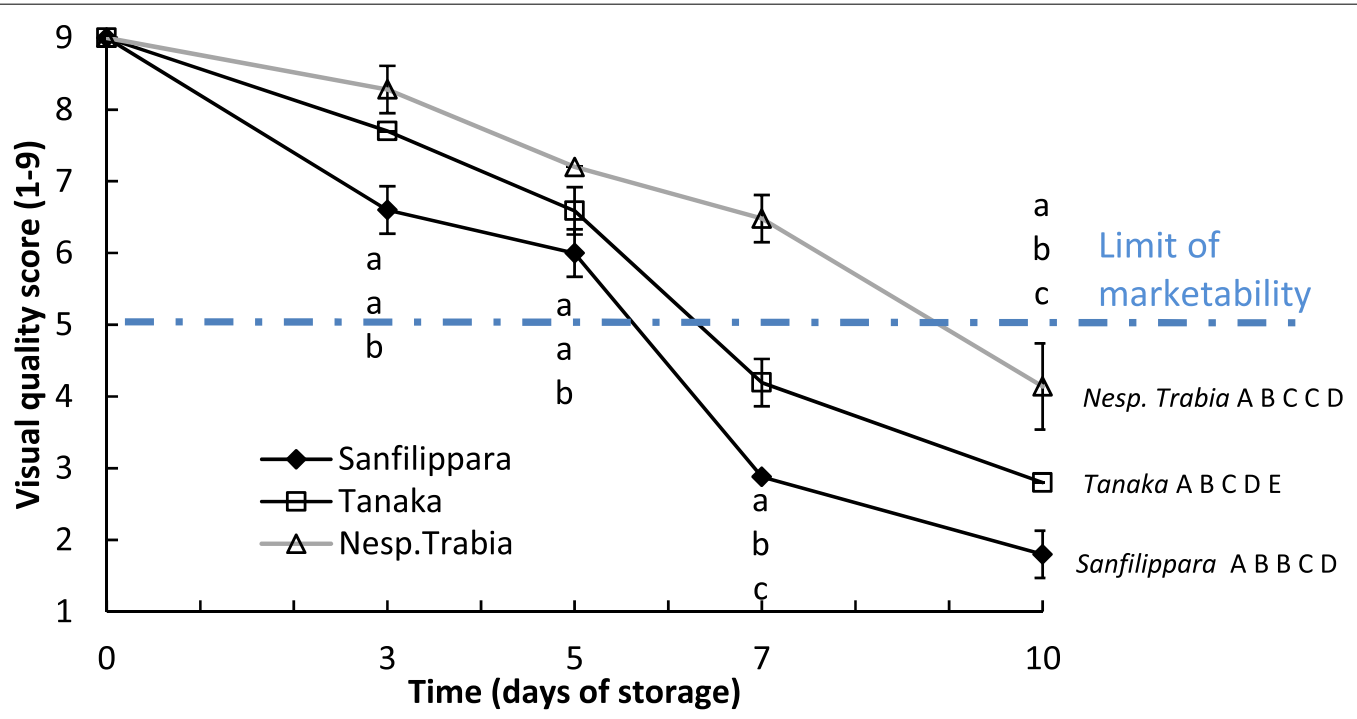

Fig. 5 Visual hedonic evaluation applied to loquat fruit cv. 'Sanfilippara', 'Tanaka' and 'Nespolone di Trabia', immediately after peeling (0) and stored for $3,5,7$ and 10 days at $5^{\circ} \mathrm{C}$. Scores are from $9=$ very good to $1=$ very poor (inedible). ( $n=10$ replicates per cultivar and sampling date). A mean score of 5 or below was taken to indicate the limit of marketability. For each cultivar, different capital letters indicate significant differences between sampling dates, and different lowercase letters indicate significant differences(Tukey's test at $p \leq 0.05$ ) between different cultivar at the same sampling date $(0,3,5,7$ and 10 days). Vertical bars represent standard error (SE) 

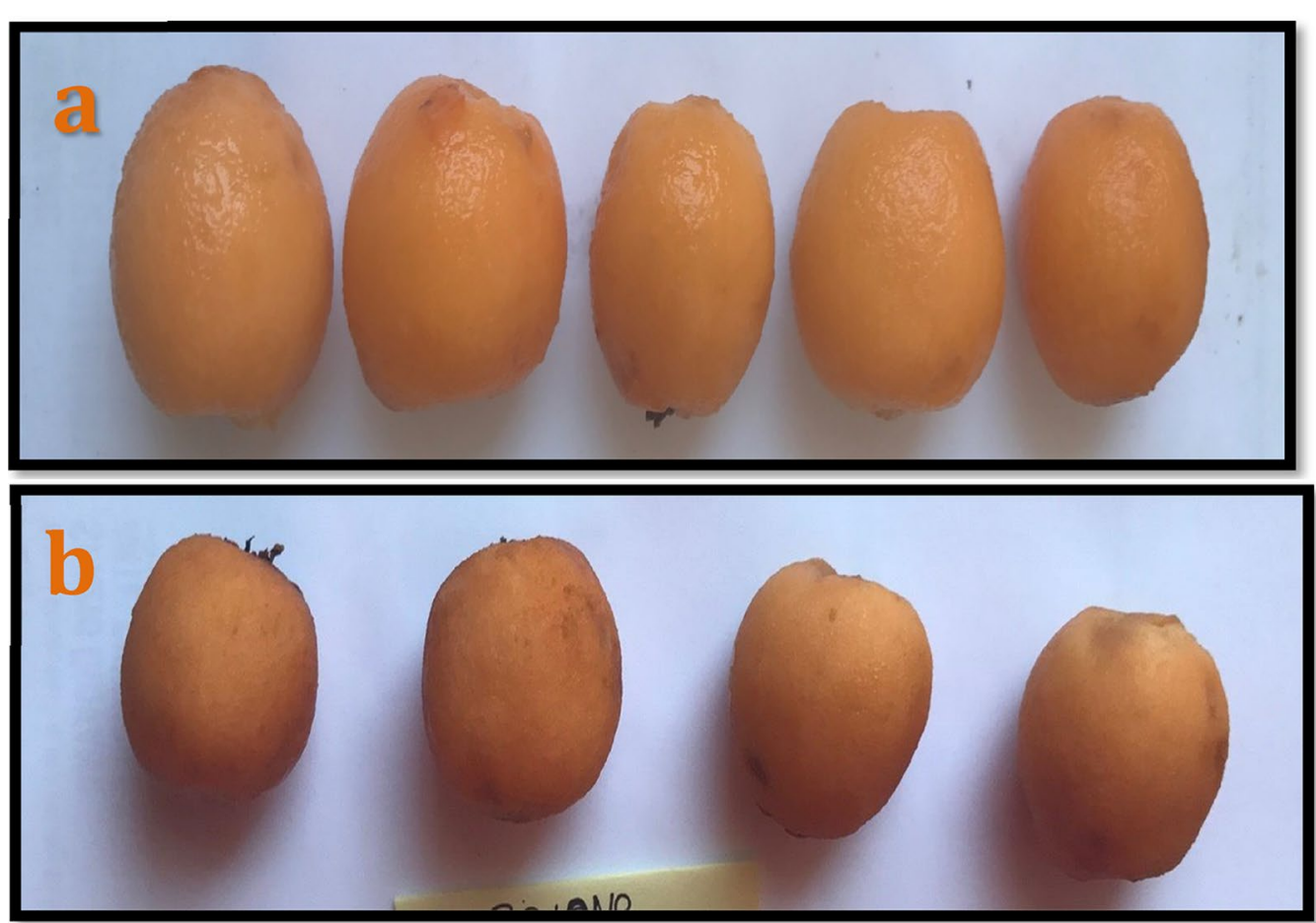

Fig. 6 Visual hedonic evaluation of cv. 'Nespolone di Trabia' (a) and cv. 'Sanfilippara' (b) after 7 days at $5{ }^{\circ} \mathrm{C}$

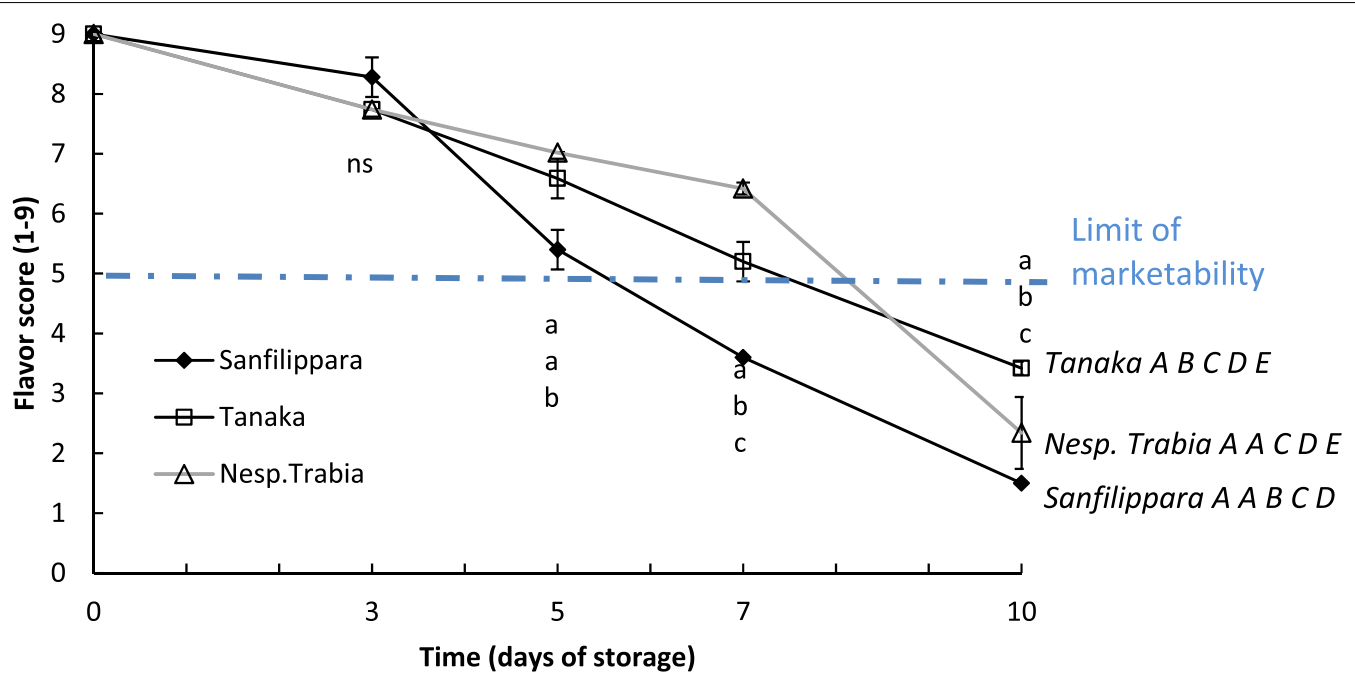

Fig. 7 Flavor hedonic evaluation applied to loquat fruit cv. 'Sanfilippara,',Tanaka' and 'Nespolone di Trabia' immediately after peeling (0) and stored for $0,3,5,7$ and 10 days at $5^{\circ} \mathrm{C}$. Data are from $9=$ very high, to no flavor $=1$ ( $n=10$ replicates per cultivars and sampling date). A mean score of 5 or below was taken to indicate the limit of marketability. For each cultivar, different capital letters indicate significant differences between sampling dates, and different lowercase letters indicate significant differences (Tukey's test at $p \leq 0.05$ ) between different cultivar at the same sampling date $(0,3,5,7$ and 10 days). Vertical bars represent standard error (SE)

an in-bag atmosphere of approximately $4 \mathrm{kPa} \mathrm{O}_{2}$ and $5 \mathrm{kPa} \mathrm{CO}$ resulting in the highest scores for appearance and chemical compounds.

\section{Carotenoids and phenols total}

According to $\mathrm{Lu}$ [48] carotenoids are synthesized and accumulated in plastid during fruit ripening. In loquat fruit $\beta$-carotene and total carotenoids are more abundant 


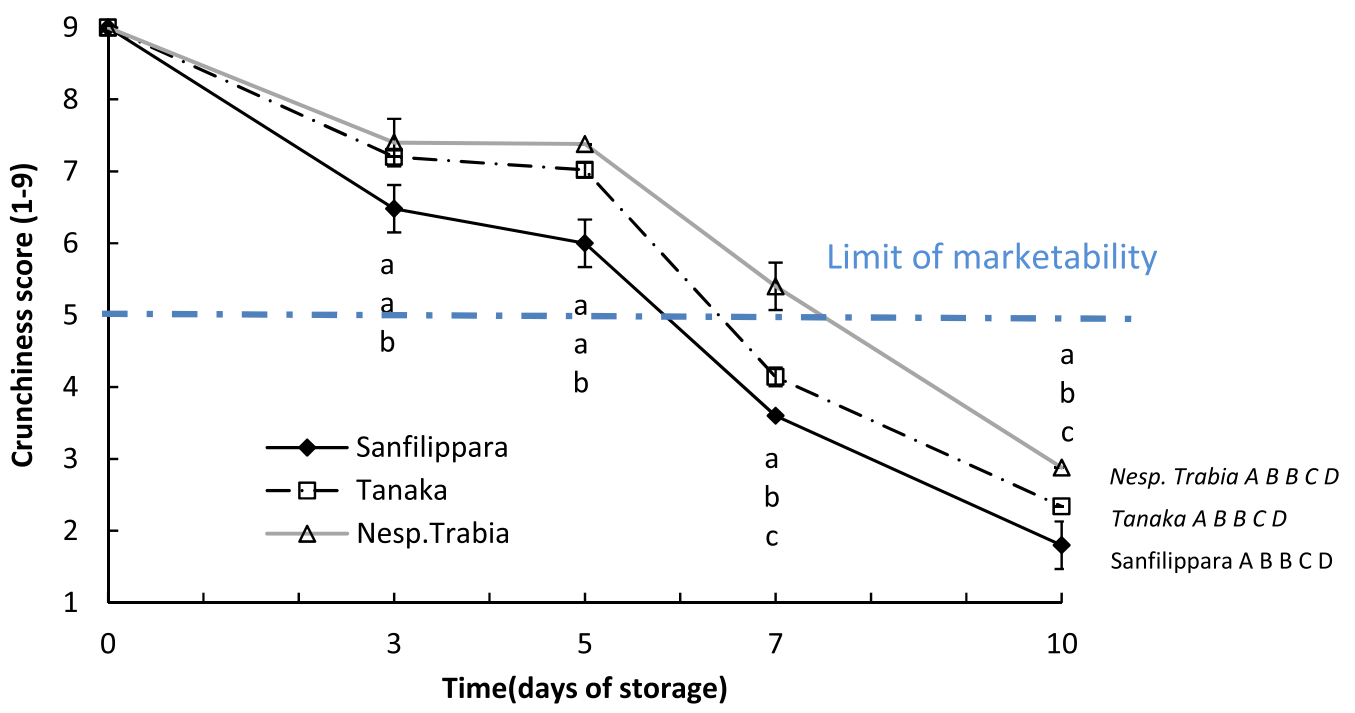

Fig. 8 Crunchiness hedonic evaluation applied to loquat fruit cv. 'Sanfilippara','Tanaka' and 'Nespolone di Trabia' immediately after peeling (0) and stored for $3,5,7$ and 10 days at $5{ }^{\circ} \mathrm{C}$. Crunchiness of each fruit was determined by ten judges, based on resistance of fruit to crunching, according to a 9-1 scale, from $9=$ very crunchy; to $1=$ crummy (inedible). Each judge analyzed a sample of 10 fruits for each cultivar at each sampling date. For each cultivar, different capital letters indicate significant differences between sampling dates, and different lowercase letters indicate significant differences (Tukey's test at $p \leq 0.05)$ between different cultivar at the same sampling date $(0,3,5,7$ and 10 days). Vertical bars represent standard error (SE)

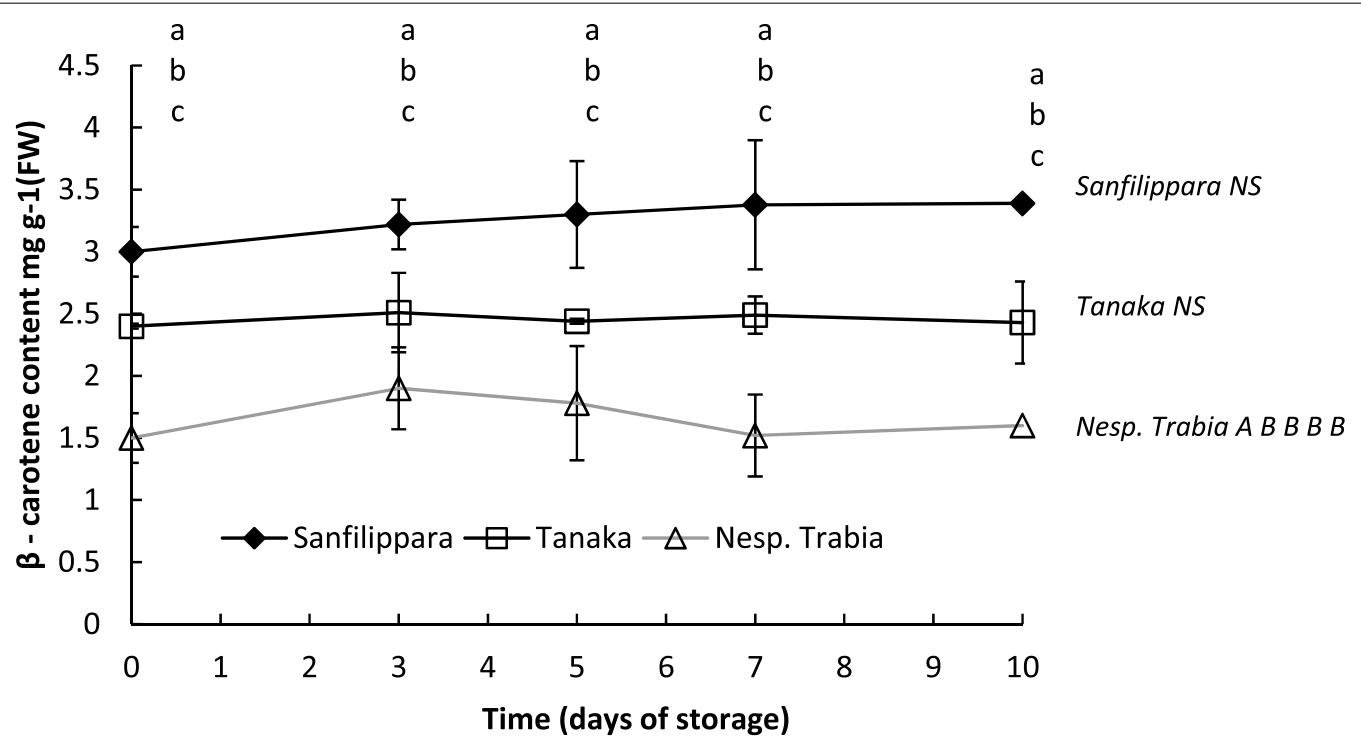

Fig. $9 \beta$-Carotene in loquat fruit cv. 'Sanfilippara,'Tanaka' and 'Nespolone di Trabia' immediately after peeling (0) and stored for 3, 5, 7 and 10 days at $5^{\circ} \mathrm{C}(n=6$ replicates per cultivars and sampling date). Different letters indicate significant differences at $p \leq 0.05$ at each sampling date

in the peel than in the flesh [48] as fig fruit [49]. However, $\mathrm{Fu}[50]$ reported that carotenoids are deposited mainly in the lipid globules in the chromoplasts of the peel, while in 'Luoyangqing' cultivar, they were also present in its flesh though in crystalline form. Genotype-related significant differences appeared immediately after storage, to be kept during the whole shelf life period (Fig. 9). Eventually, $\beta$-carotene content did not change significantly in any genotype during shelf life.

Another difference concerns the proportion of lutein in relation to genotype and total carotenoid content at 
harvest. De Faria [51] reported that the proportion of lutein in relation to total carotenoid content, was 3.3\% in cv. 'Nectar de Cristal' and from 0.2 to $0.6 \%$ in the other loquat cultivars, while [52], in cv 'Toi', have occurred that b-cryptoxanthin content was higher than that of $\beta$-carotene and lutein proportion about 4.2\%. During storage, a significant degradation of Lutein in all cultivars was observed only after 7 days of storage; at the end of the storage period Lutein content decreased by $40-60 \%$, depending on genotype. Eventually, genotype-related

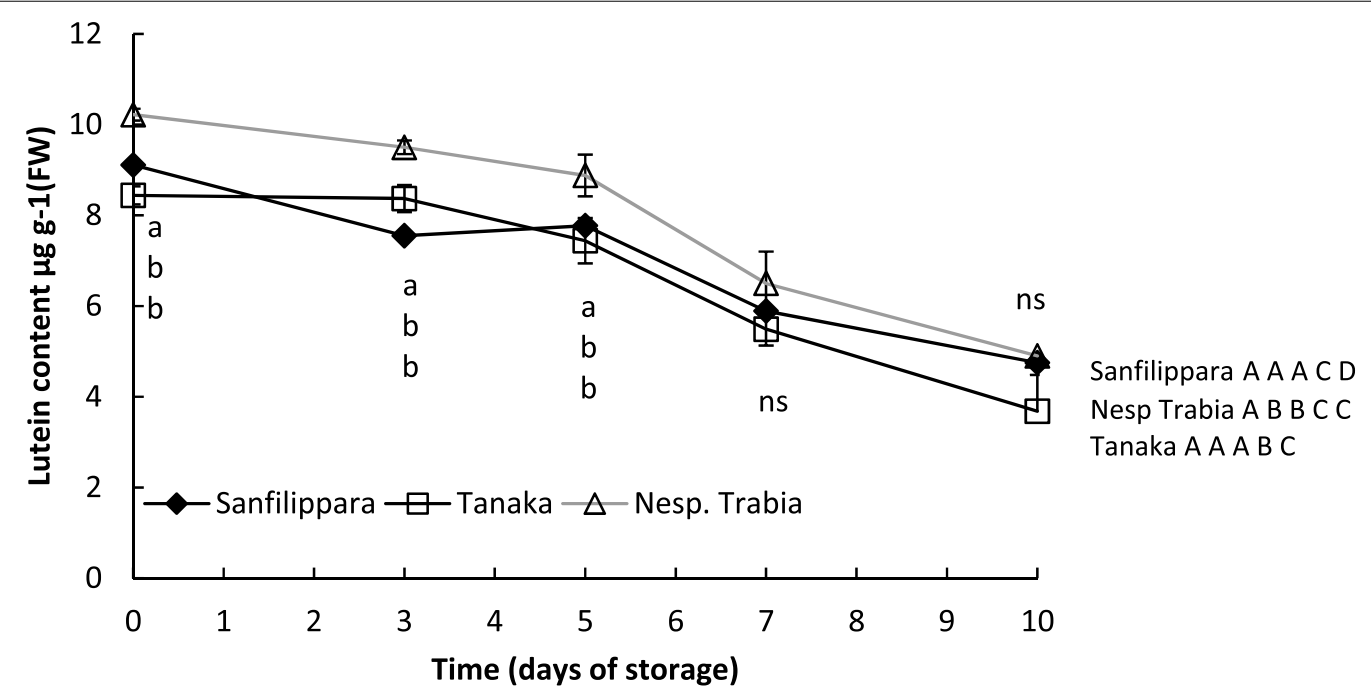

Fig. 10 Lutein content in loquat fruit cv. 'Sanfilippara,',Tanaka' and 'Nespolone di Trabia', immediately after peeling (0) and stored for 3, 5, 7 and 10 days at $5^{\circ} \mathrm{C}(n=6$ replicates per cultivars and sampling date). Different letters indicate significant differences at $p \leq 0.05$ at each sampling date

Table 4 Qualitative phenols content in loquat cv. 'San Filippara' (milligrams per $100 \mathrm{~g}$ of fresh weight) fruit during storage time 0, 3, 5, 7 and 10 days)

\begin{tabular}{|c|c|c|c|c|c|c|}
\hline \multicolumn{7}{|c|}{ 'San Filippara' } \\
\hline $\begin{array}{l}\text { Day of } \\
\text { storage }\end{array}$ & Total & 5-Caffeolyquinic acid & 3-Caffeoylquinic acid & 4-Caffeoylquinic acid & 5-Feruloyquinic acis & $\begin{array}{l}\text { Hydrowybenzoic } \\
\text { acid }\end{array}$ \\
\hline 0 & $110.77 a$ & $52.22 \mathrm{a}$ & 17.70ab & $4.33 a$ & $2.81 a$ & $3.64 a$ \\
\hline 3 & $111.22 \mathrm{a}$ & $54.33 b$ & $16.2 \mathrm{a}$ & $3.22 \mathrm{ab}$ & $3.10 \mathrm{a}$ & $3.80 \mathrm{a}$ \\
\hline 5 & $114.54 b$ & $57.62 \mathrm{c}$ & 15.98ab & $3.19 b$ & $3.97 b$ & $3.23 a$ \\
\hline 7 & $110.45 a$ & $56.22 \mathrm{c}$ & $18.88 \mathrm{c}$ & $3.43 b$ & $2.99 a$ & $1.97 \mathrm{~b}$ \\
\hline 10 & $105.44 a$ & $57.13 c$ & $15.64 a$ & $2.15 c$ & $1.23 c$ & $2.23 b$ \\
\hline
\end{tabular}

Values with different letters are significantly different at $p<0.05$

Table 5 Qualitative phenols content in loquat fruit cv. 'Tanaka', (milligrams per $100 \mathrm{~g}$ of fresh weight) during storage time 0, 3, 5, 7 and 10 days

\begin{tabular}{lllllll}
\hline \begin{tabular}{l} 
'Tanaka' \\
\hline $\begin{array}{l}\text { Day of } \\
\text { storage }\end{array}$
\end{tabular} & Total & 5-Caffeolyquinic acid & 3-Caffeoylquinic acid & 4-Caffeoylquinic acid & 5-Feruloyquinic acid & $\begin{array}{l}\text { Hydrowybenzoic } \\
\text { acid }\end{array}$ \\
\hline 0 & $115.91 \mathrm{a}$ & $61.18 \mathrm{a}$ & $19.34 \mathrm{a}$ & $3.89 \mathrm{a}$ & $4.21 \mathrm{a}$ & $4.09 \mathrm{a}$ \\
3 & $121.02 \mathrm{~b}$ & $59.35 \mathrm{~b}$ & $20.39 \mathrm{a}$ & $4.79 \mathrm{~b}$ & $5.33 \mathrm{~b}$ & $5.01 \mathrm{ab}$ \\
5 & $119.89 \mathrm{a}$ & $89.32 \mathrm{c}$ & $34.09 \mathrm{~b}$ & $3.98 \mathrm{a}$ & $4.38 \mathrm{a}$ & $4.89 \mathrm{a}$ \\
7 & $118.32 \mathrm{a}$ & $83.11 \mathrm{c}$ & $35.43 \mathrm{~b}$ & $3.74 \mathrm{a}$ & $3.98 \mathrm{a}$ & $3.32 \mathrm{~b}$ \\
10 & $113.45 \mathrm{a}$ & $82.75 \mathrm{c}$ & $31.39 \mathrm{~b}$ & $2.98 \mathrm{c}$ & $3.22 \mathrm{a}$ & $3.43 \mathrm{~b}$ \\
\hline
\end{tabular}


Table 6 Qualitative phenols content in loquatfruit cv'Nespolone di Trabia' (milligrams per $100 \mathrm{~g}$ of fresh weight) during storage time $0,3,5,7$ and 10 days

\begin{tabular}{|c|c|c|c|c|c|c|}
\hline \multicolumn{7}{|c|}{ 'Nespolone di Trabia' } \\
\hline $\begin{array}{l}\text { Day of } \\
\text { storage }\end{array}$ & Total & 5-Caffeolyquinic acid & 3-Caffeoylquinic acid & 4-Caffeoylquinic acid & 5-Feruloyquinic acis & $\begin{array}{l}\text { Hydrowybenzoic } \\
\text { acid }\end{array}$ \\
\hline 0 & $150.46 a$ & $80.32 a$ & $26.94 a$ & $6.89 a$ & $7.56 a$ & $7.65 a$ \\
\hline 3 & $145.41 b$ & $75.96 b$ & $32.33 b$ & $5.23 b$ & $8.45 b$ & $7.98 b$ \\
\hline 5 & $146.12 b$ & $77.43 b$ & $33.42 b$ & $6.02 \mathrm{a}$ & $7.42 \mathrm{a}$ & $7.44 a$ \\
\hline 7 & $130.78 c$ & $65.40 c$ & $26.90 a$ & $4.32 \mathrm{c}$ & $6.32 \mathrm{a}$ & $6.78 \mathrm{a}$ \\
\hline 10 & $127.44 \mathrm{C}$ & $61.32 \mathrm{c}$ & $27.11 c$ & $4.76 c$ & $6.23 a$ & $5.23 c$ \\
\hline
\end{tabular}

Values with different letters are significantly different at $p<0.05$

differences appeared immediately after storage to become not significant along with the decrease of lutein content in the fruit (Fig. 10).

During fruit ripening, the total phenols contents of loquats, first decreased sharply and then increased dramatically [7]. In our work (Tables 4, 5), phenols total content remained stable $(p<0.05)$ throughout the storage period and, obviously, the same occurs for genotype-related differences that occurred at time 0 .
This trend is observed on nectarine fruit [53] and on fig fruit [54] during cold storage. Different trend occurred for loquat fruit with a late ripeness stage (Table 6), the values shown a decrease of $15 \%$ during storage at $5{ }^{\circ} \mathrm{C}$. In detail, 5-caffeolyquinic acid, significant increased (Tables 3, 4), while decreased in cv 'Nespolone di Trabia' (Tables 4, 5 and 6). 3-Caffeoylquinic acid in loquat fruit shoed a different trend among cultivar 'Tanaka' cvs (Table 5) occurred a significant increase of value, while no significant change occurred in cv "Nespolone di

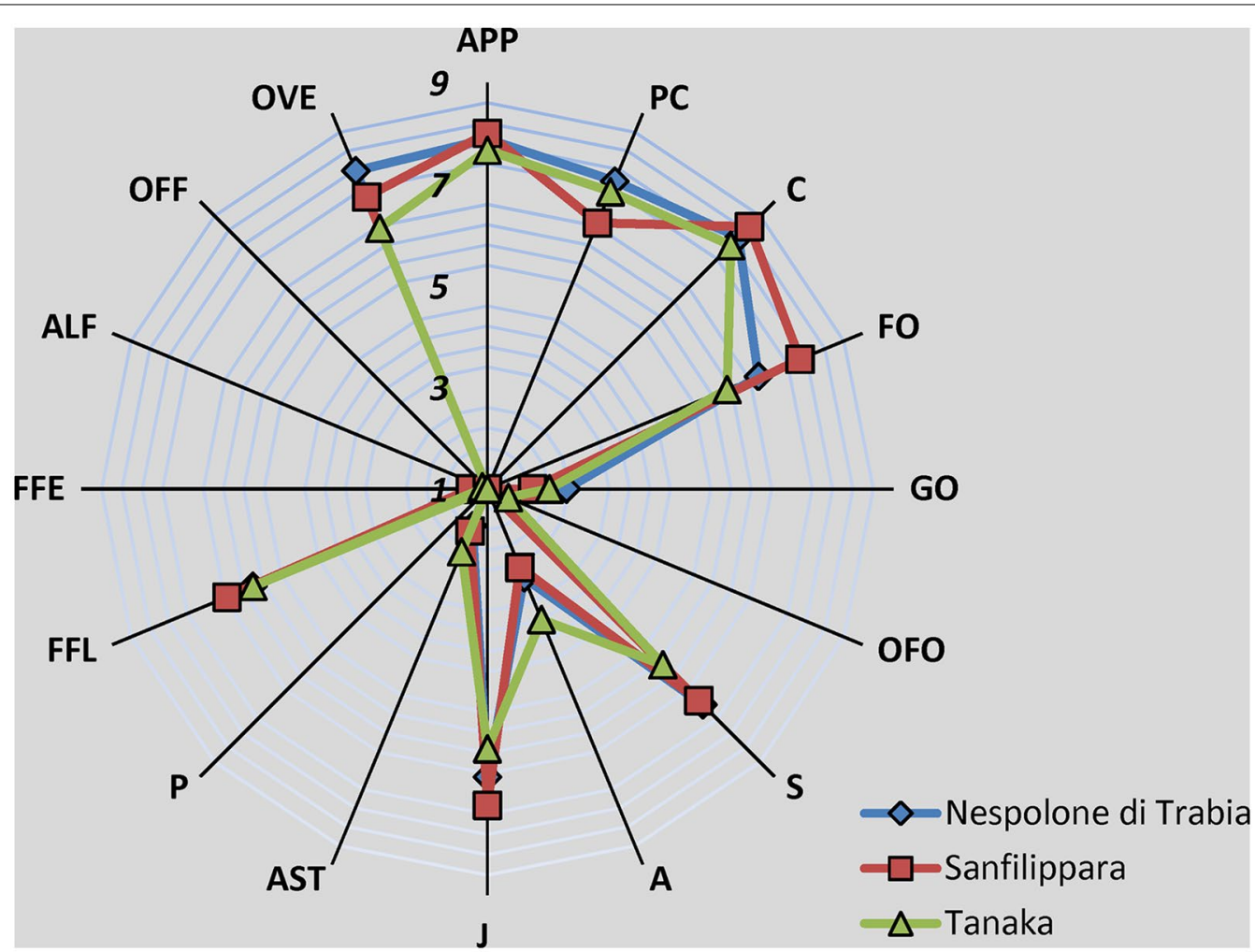

Fig. 11 Sensory analyses of minimally processed loquat at harvest (TO). Descriptors legend: Appearance (APP), pulp color (PC), Consistency $(C)$, fruity odour (FO), herbaceous odour (GO), off-odour (OFO), sweet (S), acid (A), juiciness (J), astringent (AST), pungent (P), fruity flavor (FFL), fermented flavor (FFE), flavour alcohol (ALF), off-flavour (OFF), overall evaluation (OVE) 


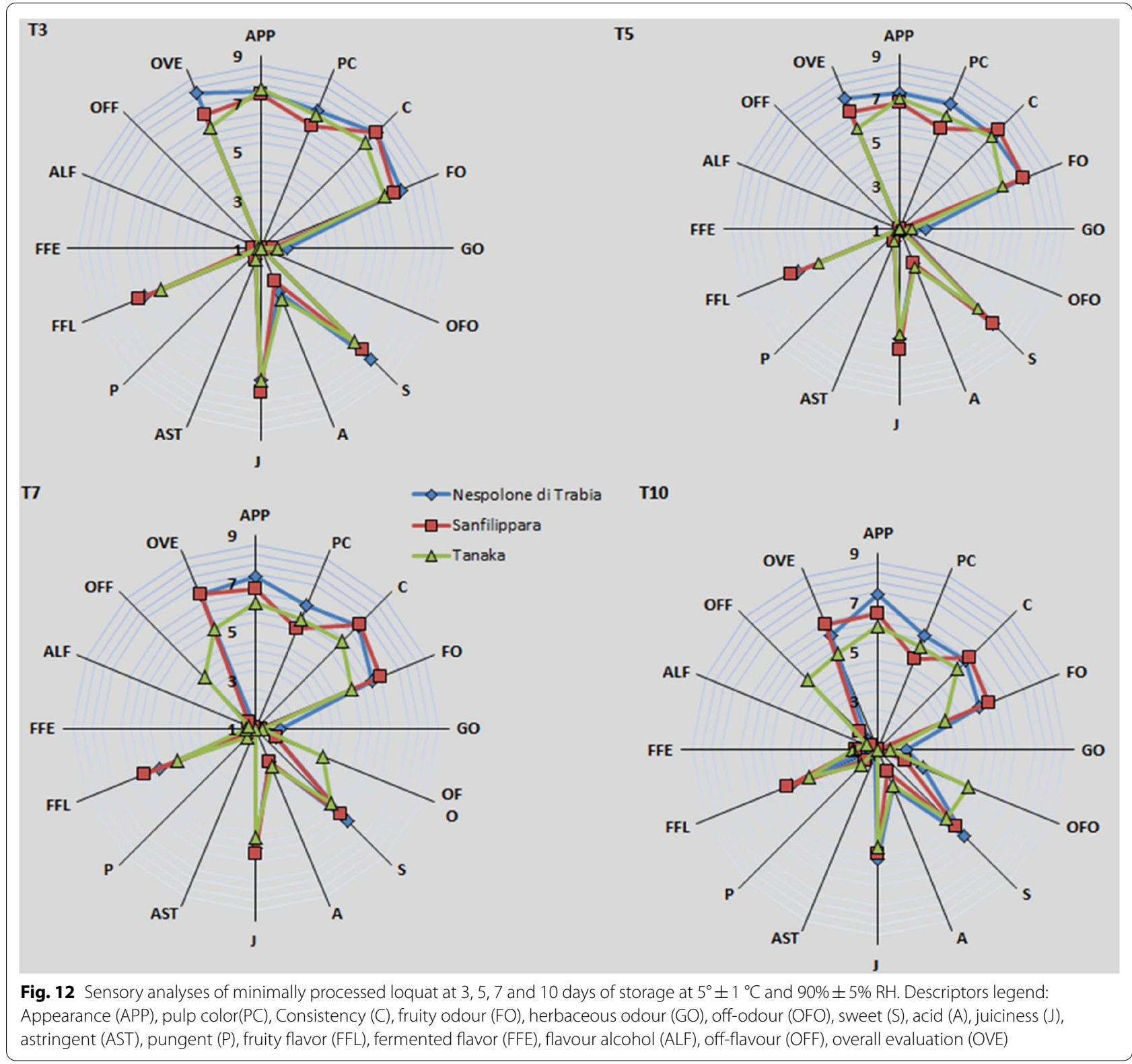

Trabia". 4-Caffeoylquinic acid, decreased in all cultivars during cold storage. 5-Feruloyquinic acid, remained stable and did not change significantly in the cvs. 'Tanaka' and 'Nespolone di Trabia', while it decreased significantly in the cv 'San Filippara', while hydroxybenzoic acid in loquat fruit decreased significant in all cultivars (Tables 5 and 6).

\section{Sensory analysis}

The sensory analysis indicated high value of overall evaluation, appearance, pulp color, consistency, fruity odor, sweet and juiciness at harvest time, with no significant influence of the genotype (Fig. 11) at harvest.
Few differences occurred between cultivars, after sensory analysis. At time 0 the genotype had poor significant effects on sensory descriptors, except for fruity odor (FO) sweetness (S) and acidity (A). These differences were smaller in T3 and T5 when overall values kept closer to T0 (Fig. 12). At T7 and T10 there was a decrease of the values of most of descriptors and the genotype effect was significant for some of them (OFF, OVE, OFO, S, C. and FFL).

At T10 the values of most of sensory descriptors were much lower than at $\mathrm{T} 0$ and $\mathrm{T} 5$ and the effect of genotype was the same as at T7. Zou [2] reported that taste differences between the cultivars can be 
explained by variations in composition and abundance of carbohydrates, organic acids, amino acids, and phenolics.

Browning, dehydration, off flavor, acethaldeide and ethanol production could be phenomena that typically develop during storage. Severe symptoms of dehydration and browning occurred after 5 and 7 days of storage at $5{ }^{\circ} \mathrm{C}$ on early genotype ('San Filippara') followed by a significant reduction of juiciness (J). Therefore, the cold storage at $5{ }^{\circ} \mathrm{C}$ along with the genetic basis of some loquat fruit, limited the loss of sensory quality during storage.

\section{Conclusions}

This study is the first contribution that describes minimally processed loquats behavior. This research provides information about loquat cultivars suitability to be minimally processed based on consumer and sensory data as well as several biochemical parameters. This study highlights the effect of genotype and harvest time for shelf life prolong. Results highlighted that the later was the maturity stage the lower was the oxidation of the pulp and its qualitative decay. The higher values of glucose, sorbitol and ascorbic acid accumulated in the cv 'Nespolone Trabia' might have contributed to a reduction in chilling injury and oxidative stress after cutting. The same results were shown on peaches of same genotypic population of white and yellow flesh [33] and on summer and late cactus pear fruits [55]. These results show that later harvest fruit have propensity to lower oxidation of pulp and to qualitative decay. Low-temperature storage extends the shelf life of loquat fruit, and its flavor tend to deteriorate at a quicker rate than appearance does. These data are reflected in the sensory analysis. In addition, the polyphenols found in peeled fruits place loquat's cv as an high-value fruit if we consider it combined with sugars and organic acids data. The results showed that storage at $5{ }^{\circ} \mathrm{C}$ could be a good market opportunity, because it is relatively inexpensive. It can be a solution in case of high costs of storage techniques at low temperatures and, last but not least, in case of high quantities of not marketable fruit because of large spots of the epicarp (as it happens often in organic production). However, there is a clear indication of a strong genotype effect that must be taken into consideration to improve loquat minimal processing. Further studies could highlight if temperature and photoperiod conditions affect carotenoid content and if this response can be linked to a more efficient antioxidative system based on increased ascorbic acid and total phenol biosynthesis during third and fourth phases of fruit maturation. This information will help to formulate new strategies for postharvest management development and seize new market opportunities toward the improvement of loquat fruits quality.

\section{Acknowledgements \\ Not applicable. \\ Authors' contributions \\ Conceptualization, AA and GS; methodology, AA and GS; software, AA,VF; validation $A A$ and $G S$ and VF; formal analysis, AA, VF and MLVDC; investigation, $A A$ and $G S$; resources, AA and GS; data curation, $A A$ and GS; writing —original draft preparation, $\mathrm{AA}$ and $\mathrm{GS}$; writing — review and editing, $\mathrm{AA}, \mathrm{GS}$ and $\mathrm{PI}$; visualization, AA and GS; supervision, AA, GS and PI; funding acquisition, AA, VF and GS. All authors read and approved the final manuscript.}

Funding

The current work was supported by the author.

Availability of data and materials

The data sets generated and analyzed during the current study are available from the corresponding author on reasonable request.

\section{Declarations}

Ethics approval and consent to participate

This study does not involve any human, animal or endangered species.

Consent for publication

Not applicable.

\section{Competing interests}

G.S. is an associate editor of Chemical and Biological Technologies in Agriculture. The rest of the authors have no conflicts of interest to declare.

\section{Author details}

'Department of Agriculture, Food and Forestry Sciences, Viale delle Scienze Ed. 4, ing. H., Palermo 90128, Italy. ${ }^{2}$ Department of Science of Agriculture, Food and Environment, University of Foggia, Via Napoli 25, Foggia 71122, Italy.

Received: 26 October 2021 Accepted: 28 December 2021

Published online: 15 January 2022

\section{References}

1. Calabrese F. Stato e prospettive della coltura del Nespolo del Giappone in Sicilia. Frutticoltura. 1986;10:55-61

2. Zou S, Wu J, Shahid MQ, He Y, Lin S, Liu Z, Yang X. Identification of key taste components in loquat using widely targeted metabolomics. Food Chem. 2020;323:126822. https://doi.org/10.1016/j.foodchem.2020. 126822.

3. Farina V, Gianguzzi G, Mazzaglia A. Fruit quality evaluation of affirmed and local loquat (Eriobotrya japonica Lindl) cultivars using instrumental and sensory analyses. Fruits. 2016;71(2):105-13. https://doi.org/10. 1051/fruits/2015053.

4. Alos E, Martinez-Fuentes A, Reig C, Mesejo C, Rodrigo MJ, Agustí M, Zacarías $L$. Ethylene biosynthesis and perception during ripening of loquat fruit (Eriobotrya japonica Lindl.). J Plant Phys. 2017;210:64-71. https://doi.org/10.1016/j.jplph.2016.12.008.

5. Reig C, Martínez-Fuentes A, Mesejo C, Rodrigo MJ, Zacarías L, Agustí M. Loquat fruit lacks a ripening-associated autocatalytic rise in ethylene production. J Plant Growth Regul. 2016;35(1):232-44. https://doi.org/ 10.1007/s00344-015-9528-3.

6. LoBianco R, Massenti R, Farina V. Metabolic promoters affect yield and fruit quality of "Sanfilippara" and 'Trabia'loquat. Acta Hortic. 2015;1092:267-72. https://doi.org/10.17660/ActaHortic.2015.1092.39.

7. Cai J, Chen T, Zhang Z, Li B, Qin G, Tian S. Metabolic dynamics during loquat fruit ripening and postharvest technologies. Front Plant Sci. 2019;10:619. https://doi.org/10.3389/fpls.2019.00619. 
8. Hadjipieri M, Christofi M, Goulas V, Manganaris GA. The impact of genotype and harvesting day on qualitative attributes, postharvest performance and bioactive content of loquat fruit. Sci Hortic. 2020;263:108891. https://doi.org/10.1016/j.scienta.2019.108891.

9. Hadjipieri M, Georgiadou EC, Costa F, Fotopoulos V, Manganaris GA Dissection of the incidence and severity of purple spot physiological disorder in loquat fruit through a physiological and molecular approach. Plant Physiol Biochem. 2020;155:980-6. https://doi.org/10.1016/j.plaphy. 2020.06.043.

10. Sánchez-Torres P, Hinarejos R, Tuset JJ. Characterization and pathogenicity of Fusicladium eriobotryae, the fungal pathogen responsible for loquat scab. Plant Dis. 2009;93(11):1151-7. https://doi.org/10.1094/ pdis-93-11-1151.

11. Pareek S, Benkeblia N, Janick J, Cao S, Yahia EM. Postharvest physiology and technology of loquat (Eriobotrya japonica Lindl.) fruit. I Sci Food Agric. 2014;94(8):1495-504. https://doi.org/10.1002/jsfa.6560.

12. Ding CK, Chachin K, Hamauzu Y, Ueda Y, Imahori Y. Effects of storage temperatures on physiology and quality of loquat fruit. Postharvest Biol Technol. 1998;14(3):309-15. https://doi.org/10.1016/s0925-5214(98) 00053-2.

13. Beaulieu JC, Ingram DA, Lea JM, Bett-Garber KL. Effect of harvest maturity on the sensory characteristics of fresh-cut cantaloupe. J Food Sci. 2004;69(7):250-8. https://doi.org/10.1111/j.1365-2621.2004.tb13624.x.

14. Chironi S, Sortino G, Allegra A, Saletta F, Caviglia V, Ingrassia M. Consumer assessment on sensory attributes of fresh table grapes $C v^{\prime} \mid$ Italia' and 'Red globe' after long cold storage treatment. Chem Eng Trans. 2017;58:421-6. https://doi.org/10.3303/CET1758071.

15. Beleski RL. Sugar alcohols. In: Loewus FA, Tanner W, editors. Plant carbohydrates. I. Intracellular carbohydrates. Encyclopedia of plant physiology, vol. 13A. Berlin: Springer; 1982. p. 158-92.

16. Borsani J, Budde CO, Porrini L, Lauxmann MA, Lombardo VA, Murray R Carbon metabolism of peach fruit after harvest: changes in enzymes involved in organic acid and sugar level modifications. J Exp Bot. 2009;60:1823-37.

17. Ma Y, Zhang Y, Lu J, Shao H. Roles of plant soluble sugars and their responses to plant cold stress. Afr J Biotechnol. 2009;8:2004-10.

18. Holland N, Menezes HC, Lafuente MT. Carbohydrates as related to the heat-induced chilling tolerance and respiratory rate of'Fortune' mandarin fruit harvested at different maturity stages. Postharvest Biol Technol. 2002;25:181-91

19. Purvis AC, Grierson W. Accumulation of reducing sugar and resistance of grapefruit peel to chilling injury as related to winter temperatures. J Am Soc Hortic Sci. 1982;107:139-42.

20. Den Ende WV, Valluru R. Sucrose, sucrosyl oligosaccharides, and oxidative stress: scavenging and salvaging? J Exp Bot. 2009;60:9-18.

21. Cao S, Yang Z, Cai Y, Zheng Y. Fatty acid composition and antioxidant system in relation to susceptibility of loquat fruit to chilling injury. Food Chem. 2011;127:1777-83.

22. Shaw PE, Wilson CW. Volatile constituents of loquat (Eriobotrya japonica Lindl) fruit. J Food Sci. 1982;47(5):1743-4. https://doi.org/10.1111/j.13652621.1982.tb05028.x.

23. Fröhlich O, Schreier P. Volatile constituents of loquat (Eriobotrya japonica Lindl.) fruit. J Food Sci. 1990;55(1):176-80.

24. Takahashi H, Sumitani H, Inada Y, Mori D, Nakano Y. Potent aroma volatiles in fresh loquat and its canned product. Nippon Shokuhin Kagaku Kogaku Kaishi. J Jpn Soc Food Sci Technol. 2000;47(4):302-10. https://doi.org/10. 3136/nskkk.47.302.

25. Ercisli S, Gozlekci S, Sengul M, Hegedus A, Tepe S. Some physicochemical characteristics, bioactive content and antioxidant capacity of loquat (Eriobotrya japonica (Thunb.) Lindl.) fruits from Turkey. Sci Hortic. 2012;148:185-9. https://doi.org/10.1016/j.scienta.2012.10.001.

26. Undurraga M, Pedro L, Olaeta C, José A, Cancino C. Ethylene, enzymatic and respiratory pattern evolution in loquat (Eriobotrya japonica (Thunb.) Lindl.) cv. Golden Nugget in the last four sequential stages of maturation. Chilean J Agric Res. 2011;71(4):530-5. https://doi.org/10.4067/s071858392011000400005

27. Amorós A, Zapata P, Pretel MT, Botella MA, Serrano M. Physico-chemical and physiological changes during fruit development and ripening of five loquat (Eriobotrya japonica Lindl.) cultivars. Food Sci Technol Int. 2003;9(1):43-51. https://doi.org/10.1177/1082013203009001007.
28. Jiang TM, Wang P, Yin XR, Zhang B, Xu CJ, Li X, Chen KS. Ethylene biosynthesis and expression of related genes in loquat fruit at different developmental and ripening stages. Sci Hortic. 2011;130(2):452-8. https://doi. org/10.1016/j.scienta.2011.07.019.

29. Cefola M, Pace B, Sergio L, Baruzzi F, Gatto MA, Carito A. Postharvest performance of fresh-cut "Big Top" nectarine as affected by dipping in chemical preservatives and packaging in modified atmosphere. Int J Food Sci Technol. 2013;49(4):1184-95. https://doi.org/10.1111/ijfs.12415.

30. Crisosto CH, Bremer V, Ferguson L, Crisosto GM. Evaluating quality attributes of four fresh fig (Ficus carica L.) cultivars harvested at two maturity stages. HortScience. 2010;45(4):707-10. https://doi.org/10. 21273/hortsci.45.4.707.

31. Gentile C, Reig C, Corona O, Todaro A, Mazzaglia A, Perrone A, Gianguzzi G, Agusti M, Farina V. Pomological traits, sensory profile and nutraceutical properties of nine cultivars of loquat (Eriobotrya japonica Lindl.) fruits grown in mediterranean area. Plant Foods Hum Nutr. 2016;71:330-8. https://doi.org/10.1007/s11130-016-0564-3.

32. Sortino G, Allegra A, Passafiume R, Gianguzzi G, Gullo G, Gallotta A. Postharvest application of sulphur dioxide fumigation to improve quality and storage ability of "red globe" grape cultivar during long cold storage. Chem Eng Trans. 2017;58:403-8.

33. Xiong ZM, Zhou CH, Tao J. Changes of carotenoid content in pulp of different loquat types during fruit coloring. Sci Agric Sin. 2007:12:2910-4.

34. Rapisarda P, Intelisano S. Sample preparation for vitamin $C$ analysis of pigmented orange juices. Ital J Food Sci. 1996;8(3):251-6. https://doi. org/10.1021/ed054p192.

35. Pinillos V, Hueso JJ, Marcon Filho JL, Cuevas J. Changes in fruit maturity indices along the harvest season in 'Algerie' loquat. Sci Hortic. 2011;129(4):769-76. https://doi.org/10.1016/j.scienta.2011.05.039.

36. Allegra A, Sortino G, Farina V, Inglese P. Effect of passive atmosphere and chemical treatment on fresh cut of white-flesh peach cultivar "Settembrina Di Bivona." Acta Hortic. 2015;1084:765-70. https://doi. org/10.17660/ActaHortic.2015.1084.103.

37. Kader AA. Biochemical and physiological basis for effects of controlled and modified atmospheres on fruits and vegetables. Food Technology (USA). 1986.

38. Lu C, Toivonen PM. Effect of 1 and $100 \mathrm{kPa} \mathrm{O}_{2}$ atmospheric pretreatments of whole 'Spartan' apples on subsequent quality and shelf life of slices stored in modified atmosphere packages. Postharvest Biol Technol. 2000;18(2):99-107. https://doi.org/10.1016/s0925-5214(99)00069-1.

39. Gao HY, Chen HJ, Chen WX, Yang YT, Song LL, Jiang YM, Zheng YH. Effect of hypobaric storage on physiological and quality attributes of loquat fruit at low temperature. Acta Hortic. 2006;712:269-74. https:// doi.org/10.17660/ActaHortic.2006.712.29.

40. Allegra A, Barone E, Inglese P, Todaro A, Sortino G. Variability of sensory profile and quality characteristics for 'Pesca di Bivona' and 'Pesca di Leonforte' peach (Prunus persica Batsch) fresh-cut slices during storage. Postharvest Biol Technol. 2015;110:61-9. https://doi.org/10.1016/j.posth arvbio.2015.07.020.

41. Kader AA. Postharvest technology of horticultural crops. University of California, 535, ANR Publication 3311. 2002.

42. Tavarini S, Trinci L, Degl'Innocenti E, Guidi L. Different sensitivity to browning in fresh-cut pineapple, apple and pear: the role of endogenous vitamin C. Ital J Food Sci. 2010;22(2):171.

43. Sortino G, Saletta F, Puccio S, Scuderi D, Allegra A, Inglese P, Farina V. Extending the shelf life of white peach fruit with 1-methylcyclopropene and aloe arborescens edible coating. Agriculture. 2020;10(5):151. https:// doi.org/10.3390/agriculture10050151.

44. Allegra A, Gallotta A, Carimi F, Mercati F, Inglese P, Martinelli F. Metabolic profiling and post-harvest behavior of "Dottato" Fig (Ficus carica L.) fruit covered with an edible coating from O Ficus-indica. Front Plant Sci. 2018;9:1321. https://doi.org/10.3389/fpls.2018.01321.

45. Cai C, Xu C, Li X, Ferguson I, Chen K. Accumulation of lignin in relation to change in activities of lignification enzymes in loquat fruit flesh after harvest. Postharvest Biol Technol. 2006;40(2):163-9. https://doi.org/10. 1016/j.postharvbio.2005.12.009.

46. Kahramanoğlu I. Preserving postharvest storage quality of fresh loquat fruits by using different bio-materials. J Food Sci Technol. 2020;57:300412. https://doi.org/10.1007/s13197-020-04333-5. 
47. Ding CK, Chachin K, Ueda Y, Imahori Y, Wang CY. Modified atmosphere packaging maintains postharvest quality of loquat fruit. Postharvest Biol Technol. 2002;24(3):341-8. https://doi.org/10.1016/s0925-5214(01) 00148-X.

48. Lu S, Li L. Carotenoid metabolism: biosynthesis, regulation, and beyond. J Integr Plant Biol. 2008;50(7):778-85.

49. Allegra A, Alfeo V, Gallotta A, Todaro A. Nutraceutical content in "Melanzana" and "Dottato" fig fruit (Ficus carica L.). Acta Hortic. 2017;1173:319-22. https://doi.org/10.17660/ActaHortic.2017.1173.55.

50. Fu X, Kong W, Peng G, Zhou J, Azam M, Xu C, Chen K. Plastid structure and carotenogenic gene expression in red-and white-fleshed loquat (Eriobotrya japonica) fruits. J Exp Bot. 2012;63(1):341-54.

51. De Faria AF, Hasegawa PN, Chagas EA, Pio R, Purgatto E, Mercadante AZ Cultivar influence on carotenoid composition of loquats from Brazil. J Food Comp Anal. 2009;22(3):196-203. https://doi.org/10.1016/j.jfca.2008. 10.014 .

52. Kon M, Shimba R. Cultivar difference of carotenoids in loquat fruits. J Jpn S Food Sci Technol. 1988;35:423-9. https://doi.org/10.3136/nskkk1962. 35.6_423.

53. Gallotta A, Allegra A, Inglese P, Sortino G. Fresh-cut storage of fruit and fresh-cuts affects the behaviour of minimally processed Big Bang nectarines (Prunus persica L. Batsch) during shelf life. Food Packag Shelf Life. 2018;15:62-8. https://doi.org/10.1016/j.fpsl.2017.11.004.

54. Ingrassia M, Chironi S, Allegra A, Sortino G. Consumer preferences for fig fruit (Ficus carica L.) quality attributes and postharvest storage at low temperature by in-store survey and focus group. Acta Hortic. 2017:1173:383-8.

55. Allegra A, Sortino G, Miciletta G, Riotto M, Fasciana T, Inglese P. The influence of harvest period and fruit ripeness at harvest on minimally processed cactus pears (Opuntia ficus-indica L. Mill) stored under passive atmosphere. Postharvest Biol Technol. 2015;104:57-62.

\section{Publisher's Note}

Springer Nature remains neutral with regard to jurisdictional claims in published maps and institutional affiliations.

\section{Submit your manuscript to a SpringerOpen ${ }^{\odot}$ journal and benefit from:}

- Convenient online submission

- Rigorous peer review

- Open access: articles freely available online

- High visibility within the field

- Retaining the copyright to your article

Submit your next manuscript at $\boldsymbol{\nabla}$ springeropen.com 